\title{
The Economy and Governance as Determinants of Political Trust in Europe: An Analysis of the European Values Study and World Values Survey, 1990-2019*1
}

\author{
MARTA KOŁCZYŃSKA** \\ Institute of Political Studies of the Polish Academy of Sciences, Warsaw
}

\begin{abstract}
Trust in state institutions is essential for the stability and legitimacy of political regimes. Understood in evaluative terms, political trust has often been linked to the performance of the state and its institutions. The macrolevel sources of trust, however, are not well understood owing to the scarcity of empirical tests beyond cross-sectional analyses. This paper examines economic performance and the quality of governance as determinants of political trust in Europe. The analysis relies on data from the European Values Study and the World Values Survey between 1990 and 2019, covering 42 European countries surveyed at least twice. The modelling strategy explicitly distinguishes between-country variation from within-country variation in macrolevel characteristics, enabling the examination of cross-national and longitudinal effects. The results provide evidence of associations between economic performance - economic development and unemployment - and political trust in the expected directions, with some differences across European regions. Further, countries with less corruption tend to enjoy higher political trust, but the effects of changes in the level of corruption on trust depend on the corruption indicator used. Finally, improvements in the quality of electoral democracy are associated with declines in political trust.
\end{abstract}

Keywords: political trust, public opinion, institutional performance, economic development, unemployment, democracy, corruption, cross-national research Sociologický časopis/Czech Sociological Review, 2020, Vol. 56, No. 6: 791-833 https://doi.org/10.13060/csr.2020.051

\footnotetext{
* This study was supported by the Polish National Science Centre (2019/32/C/HS6/ 00421).

** Direct all correspondence to: Marta Kołczyńska, Institute of Political Studies of the Polish Academy of Sciences, ul. Polna 18/20, 00-625 Warszawa, Poland, e-mail: mkolczynska@ isppan.waw.pl.

1 Replication materials are available at https://osf.io/cqvg8/.
}

(C) Sociologický ústav AV ČR, v. v. i., Praha 2020 


\section{Introduction}

Trust in political institutions refers to the belief of citizens that these institutions will perform their duties even if exposed to little supervision or scrutiny [Easton 1965]. Political trust features prominently in the sociological and political science literatures, owing much of this interest to the theorised link between political trust and state legitimacy [Brehm and Rahn 1997; Easton 1965, 1975; Klingemann 1999; Norris 2002; Seligson 2002]. Declines in political trust have been lamented as threatening the stability of democratic regimes [Dalton 2004], depleting the reservoir of support for institutions and authorities, lowering compliance with government regulations and civic duty [Letki 2007; Oksanen et al. 2020; Salmon et al. 2009; Tyler 1990, 1998], increasing opposition to government programmes [Davis and Silver 2004], and also raising concerns about a greater acceptance of illegal behaviour [Marien and Hooghe 2011]. Examining the correlates of political trust, numerous studies have shown that trust is higher in countries with better institutional performance [Miller 1974; Mishler and Rose 2001a], higher economic development, and lower unemployment [Lewis-Beck 1988; Listhaug and Wiberg 1995; McAllister 1999; Mishler and Rose 1997]. However, since most of these studies rely on cross-country comparisons, it remains unclear whether the associations observed between countries hold when changes are examined over time. Indeed, the scarcity of empirical tests beyond cross-sectional analyses has been identified as a major weakness of this research area [Dalton 2004; Marien and Hooghe 2011; van der Meer and Zmerli 2017].

This paper examines trends in political trust and its associations with economic performance and quality of governance in 42 European countries between 1990 and 2019. The analysis relies on cross-national repeated cross-sectional data collection combining the European Values Study and the World Values Survey, taking advantage of the projects' Europe-wide coverage and long timespan. The modelling strategy enables the distinction between cross-country and over-time effects of performance on trust. According to the results, while political trust has remained relatively stable in much of Western Europe over the last 30 years, Central and Eastern Europe - the 'new' European Union and the non-EU countries - saw greater volatility in political trust, including substantial increases (e.g. Estonia) and considerable declines (e.g. Croatia). The analysis also shows that economic performance is positively associated with political trust, with some differences between regions. At the same time, countries with less corruption tend to enjoy higher political trust, but the effects of within-country changes in corruption depend on the choice of the corruption indicator. Finally, the results point to a negative association of within-country changes in the quality of democracy and political trust.

The paper is structured as follows. I begin by reviewing the literature on the evaluative nature of political trust, as well as on trust's associations with economic performance and the quality of governance. Second, I describe the individual- and macro-level data used in the analysis as well as the modelling strategy, 
followed by an overview of the trends in political trust in Europe in the last three decades. Next, I turn to the results, and then I conclude with a discussion of the study's theoretical and methodological implications.

\section{Political trust and its sources}

Trust can be defined as a 'rational or affective belief in the benevolent motivation and performance capacity of another party' [Norris 2011: 19]. The assessment of trustworthiness depends on the characteristics of the trustor, the trustee, and the issue at stake, making trust a relational concept [Hardin 2002]. Within the levels of system support, political trust occupies mid-range positions on the spectrum of specific to diffuse support, located closer to the most specific approval of incumbents than to the most diffuse endorsement of regime values and core principles [Easton 1965, 1975; Norris 1999, 2011]. As such, political trust is considered more volatile than, for example, support for democratic values, and is tied to perceptions about the functioning of state institutions.

While multiple studies have analysed individual attributes of the trustors, including socio-demographic characteristics and subjective evaluations of institutional performance, the focus of this paper is on the object of trust, i.e. the state and its institutions. Conceptual frameworks for evaluating characteristics of the trustee generally make a distinction between the result or outcome of the interaction, and of the process, with the latter conceptualised differently in different models depending on the context of application. With regard to trust in organizations, Mayer, Davis, and Schoorman [1995; cf. also Schoorman, Mayer and Davis 2007] proposed a scheme in which the assessment of trustworthiness depends on the trustee's ability, benevolence, and integrity. Ability refers to competence, skills, and expertise in the relevant domain of activity. Benevolence indicates that the trustee cares about the trustor's interests and thus has to do with the trustee's intentions and motives. We can speak of integrity when the values that the trustee represents are acceptable to the trustor, a concept similar to value congruence defined as the compatibility of an employee's beliefs and values with the organization's cultural values' [Sitkin and Roth 1993: 368] or 'the beliefs citizens hold about the normative appropriateness of government structures, officials, and processes' [Sacks, Tyler and Levi 2009: 354].

Others have developed alternative schemas of the characteristics of trustee that increase trustworthiness. Barber [1983] argued about the role of competence and fiduciary responsibility, while Kasperson at al. [1992] defined trust as an evaluation of social relations in four dimensions: commitment, competence, caring, and predictability. With regard to the determinants of support for democracy, Bratton and Mattes [2001] distinguish between intrinsic performance evaluation, referring to the essential features of democratic systems, and instrumental evaluations, pertaining for example, to material living standards. Despite 
the differences, all these approaches distinguish between competence or ability and arguably more subjective characteristics referring to integrity, benevolence, or value congruence. This distinction is particularly relevant when analysing the sources of trust in state institutions.

The ability of the political system can be best judged on the basis of economic performance. While macroeconomic conditions are not entirely shaped by state institutions, especially in the current state of globalisation of the economy, research has shown that citizens evaluate state institutions through economic performance, for which they hold the state responsible [Lewis-Beck 1988; Mishler and Rose 1997]. Trust has been shown to be associated with GDP per capita, an indicator of the standard of living and economic well-being and the most common measure of economic performance, as well as with unemployment [Morlino and Quaranta 2014; Muro and Vidal 2017]. The link between unemployment and political trust may operate on two levels. On the macro level, high unemployment creates unfavourable conditions for employees and increases labour market insecurity, which has a negative effect on political trust [Wroe 2014]. On the individual level, unemployment reduces well-being, life satisfaction, and self-esteem, and is associated with negative perceptions of the political system, which is blamed for an individual's misfortunes [Bauer 2018].

The lack of corruption and adherence to democratic values and principles is frequently interpreted in terms of benevolence and integrity. Public sector corruption entails betraying the public interest in favour of individual gains, and the associated partiality and abuse of discretionary powers not only objectively weaken institutions but also hurt the image of institutions in society [Rothstein and Teorell 2008]. Immunity to corruption may be understood as a matter of individual integrity or as a property of institutions and institutional arrangements, including procedures, mechanisms, and entities whose purpose is to assure compliance of actors [Miller 2017], which brings it closer to an issue of institutional performance. The quality of governance also includes guaranteeing civil rights and individual freedoms and ensuring and maintaining the rule of law and respect for democratic principles [Mishler and Rose 1997]. These properties make the state predictable for the citizens, which is an important aspect of trustworthiness.

While the theoretical connection between economic performance, quality of governance, and political trust seems straightforward, empirical research in this area has yielded mixed results. In cross-national analyses, the most consistent predictor of political trust is corruption [Hakhverdian and Mayne 2012; della Porta 2000; You 2018]. Some studies have also found an effect of macroeconomic indicators on political trust, but these effects seems to depend on whether corruption is included as a control variable [van der Meer 2017].

Examining cross-national associations between levels of political trust and state performance is informative in descriptive terms. Yet, if the relationship is causal, changes in performance over time should be associated with changes in 
political trust independent of cross-country associations. Only a few studies have examined the effects of economic performance on trust in a longitudinal perspective. Van Erkel and van der Meer [2016] analysed Eurobarometer data between 1999 and 2011 from 15 'old' European Union Member States and found economic growth to have a positive effect and corruption to have a negative effect on political trust, controlling for a number of other macro-level characteristics. Kroknes, Jakobsen and Grønning [2015] used data from rounds 2-5 of the European Social Survey covering 25 countries between 2002 and 2010, and found that increases in the growth rate of GDP per capita and changes in GDP per capita were associated with increases in political trust. However, these models did not distinguish between- from within-country effects, so they cannot be interpreted in longitudinal terms. Bargsted, Somma and Castillo [2017] examined the same phenomenon in 17 Latin American countries with data from the Latinobarometer between 2002 and 2011 and found a positive effect of economic development on within-country changes of political trust.

The present study contributes an analysis of Europe over the last 30 years. This research is exploratory and does not specify a priori hypotheses for formal testing. Rather, the study aims to describe the associations between political trust, economic performance, and the quality of governance to enable addressing the following questions. First, is political trust associated with economic performance and quality of governance? Second, are the associations due to cross-national differences or over-time changes in performance? Theories of the determinants of political trust make causal claims, and while empirical studies on the topic tend to rely on cross-national differences, making inferences about longitudinal relationships based on between-country associations is not straightforward. Thus, identifying the effects of within-country changes in macro-level characteristics constitutes a stronger test of the causal association and a more direct way of studying social change.

The final question deals with the presence and character of differences with regard to the above associations between European regions. Prior research has repeatedly found systematic differences in the levels of trust in Europe, where trust is higher in Western Europe than in Central-Eastern Europe, and attributed them to cultural or historical legacies [Torcal and Montero 2006] and institutional characteristics, including those of the electoral and party systems [Criado and Herreros 2007; van der Meer 2010]. Beyond the variation in the level of trust, we know little about the differences in the determinants of trust across European regions. Overall, much of the research on political engagement deals with Western Europe, while there is reason to expect that the same associations do not hold universally.

In post-communist countries, attitudes towards the state are likely to be shaped by the legacy of communist rule [Pop-Eleches and Tucker 2011; Rose-Ackerman 2001], the ongoing experience with state institutions [Mishler and Rose 2001b], and expectations and aspirations formed on the basis of comparisons with Western democracies. These factors, in addition to the 'post-honeymoon ef- 
fect' [Catterberg and Moreno 2006], when the initial optimism with the new institutions had faded, serve as explanations of the generally low levels of political trust in Central and Eastern Europe.

Among post-communist countries in Europe, the dividing line is between countries that pursued the path of democratic consolidation and economic reform and subsequently became members of the European Union in the 2000s and those that remain outside the EU. This distinction is associated with the success of the post-communist transition traced back to pre-communist mass schooling and its nationalist content [Darden and Grzymala-Busse 2006], as well as historical legacies and experiences of democratic governance, and overlaps with contemporary differences in economic performance and democratic consolidation. Hence, if political trust is primarily driven by the performance and integrity of state institutions, it should be higher among the new EU Member States than in the non-EU Eastern European countries. It is also possible, however, that the overall lower level of economic development in these countries changes the relative importance of economic and governance-related aspects of institutional functioning, so that aspects associated with security are preferred to aspects associated with opportunities, corresponding to the 'utility ladder of freedoms' [Welzel 2013]. At the same time, non-EU Eastern Europeans are generally assessed as not fully free or democratic [Freedom House 2020], where trust may be driven from other characteristics of state institutions and their performance than in full democracies. These differences are reflected, among others, in the association between education and trust, which is positive in consolidated democracies and negative in non-democracies [Kołczyńska 2020]. Overall, examining differences in the determinants of political trust in these three regions may illuminate the mechanisms that shape trust in different political, social, and economic contexts.

\section{Data and methods}

Data come from the European Values Study [European Values Study 2015; Gedeshi et al. 2020] and World Values Survey [Inglehart et al. 2014], limited to surveys from European countries. After eliminating surveys that do not contain one or more of the necessary variables and samples from countries surveyed only once, the final dataset contains 169 surveys from 42 countries from EVS 2-5, and WVS 2, 3, 5, 6. ${ }^{2}$ I excluded records with missing values on any of the variables. Since the focus of the analysis is on adults, data from respondents below the age of 18 have been removed. The list of countries, years, and project rounds in the final sample is available in the Appendix, Table A1.

\footnotetext{
2 The question about trust in the justice system was not asked in WVS/4. The survey documentation provides definitions of target populations, information about the sampling design, survey mode, non-response, and other aspects of the fieldwork process.
} 


\section{Variables}

\section{Political trust}

Survey questions on political trust are generally of two types. The first is the trust in government scale from the American National Election Survey, which asks respondents (a) how often the government can be trusted to do what is right, (b) whether the government is run by a few big interests, (c) whether people in the government are wasteful or $(\mathrm{d})$ crooked. While this scale better fits into the 'willingness to accept vulnerability' concept of trust [cf. Hamm, Smidt and Mayer 2019; Poznyak et al. 2014], it has been argued that it measures trust in the incumbent government [Craig, Niemi and Silver 1990], rather than a diffuse system support in the sense used by Easton [1965].

The second measurement approach, which dominates cross-national studies, relies on questions about trust in different institutions. Some analyses rely on single indicators, most often on trust in parliament [Catterberg 2013; Dalton, Van Sickle and Weldon 2010; Závecz 2017]. Others use multi-indicator measures consisting of different configurations of institutions [Breustedt 2017], with decisions guided by both theoretical considerations and availability. Since the theoretical literature tends to discuss political trust as a diffuse attitude towards regime institutions, and because of reliability concerns, measures that include trust in different institutions are preferred over single items. Given that empirical analyses point to the unidimensional structure of judgements of trustworthiness regarding different state institutions ${ }^{3}$ [Hooghe 2011], I follow the multi-indictor approach, and measure trust in state institutions with three items referring to trust in the national parliament, the justice system, and the civil service - three basic institutions to democratic states. ${ }^{4}$

The three trust items are coded on a four-point descending scale, with only small differences in question wording between the two survey projects. ${ }^{5}$ The political trust index is constructed as the sum of the values on the three trust variables, reversed - to have higher values correspond to more trust - and rescaled into the 0-10 range for ease of interpretation.

\footnotetext{
${ }^{3}$ Multi-group factor analysis with the alignment method [Asparouhov and Muthén 2014] shows that this three-item political trust scale meets the requirements for approximate scalar invariance, which enables inter-group comparisons of both correlations and means. The results of these analyses are available in the Appendix, Table A4.

${ }^{4}$ Frequently political parties are also included in the political trust index [e.g. McAllister 1999; Miller and Listhaug 1999; Morlino and Quaranta 2014; Zmerli and Castillo 2015]; however, this variable is not available in all EVS waves.

${ }^{5}$ In the EVS Round 5 questionnaire [European Values Study 2018] the question read: Please look at this card and tell me, for each item listed, how much confidence you have in them, is it a great deal, quite a lot, not very much or none at all? In the WVS Round 6 master questionnaire [World Values Survey 2012] the question read: I am going to name a number of organizations. For each one, could you tell me how much confidence you have in them: is it a great deal of confidence, quite a lot of confidence, not very much confidence or none at all?
} 


\section{Economic performance and governance indicators}

Macro-level data include indicators of economic performance and quality of governance from different sources. Data on gross domestic product per capita [World Development Indicators 2020a] refer to the standard of living, and are represented in 10000 USD to facilitate computation. It is worth noting that within-country changes in GDP per capita indicate economic performance, while between-country differences rather reflect differences in economic development. The unemployment rate is defined as the proportion of the unemployed in the total labour force [World Development Indicators 2020b].

To measure corruption I use two indicators: First, the public sector corruption index from the Varieties of Democracy (V-Dem) project, which combines the ratings on public sector bribery and embezzlement by country experts [Coppedge et al. 2020]. The second one is the Bayesian Corruption Indicator created from a variety of data sources, including population surveys and expert assessments, that refer to public perceptions of corruption and are available in the Quality of Government Institute Dataset [Dahlberg et al. 2020; Standaert 2015]. ${ }^{6}$. The values of the QOG indicator, originally ranging from 0 to 100 , were divided by 100 to facilitate comparability with the V-Dem indicators measured on a $0-1$ scale.

Interestingly, while the correlation between both indicators for the sample included in the analysis equals 0.79 , this is almost entirely due to the correlation between country means of country-year values $(r=0.82)$ and not deviations from these means $(r=0.02)$. Similar but smaller differences have been noticed in Standaert's [2015] comparison of the Bayesian Corruption Indicator with the Corruption Perceptions Index and Worldwide Governance Indicator's Control of Corruption measure. These discrepancies are consequential for the model results and this will be discussed below. ${ }^{7}$

Finally, I use V-Dem's electoral democracy index to measure the quality of democracy. The index assesses the extent to which the country's elections are free and fair, and - also between elections - the functioning of freedom of expression and independent media representing diverse viewpoints [Coppedge et al. 2019: 39].

\footnotetext{
${ }^{6}$ Other international indicators of corruption, such as the Control of Corruption component of the Worldwide Governance Indicators [Kaufmann, Kraay, and Mastruzzi 2010] and Transparency International's Corruption Perception Index, are only available as of the mid-1990s, which makes them not applicable in the present analysis, while CPI additionally has limited comparability over time [Transparency International 2020: 26].

7 The two corruption indicators use different source data (expert surveys in the case of the V-Dem Public sector corruption index and a host of different data sources on corruption perception in the case of the Bayesian Corruption Indicator) and estimation procedures (both indicators are model-based, but the models differ with regard to, among others, the modeling of time). A closer examination of both elements could identify the sources of the observed differences. Discrepancies in indicators of governance and regime change are also discussed by Lueders and Lust [2018] and Kołczyńska and Bürkner [2020].
} 


\section{Regions}

To examine differences in the effects of macro-level characteristics on political trust, I divide European countries into three groups depending on their democratic history and current status. The first group includes non-EU countries from Eastern Europe, the Western Balkans, and the Caucasus: Albania, Armenia, Azerbaijan, Belarus, Bosnia-Herzegovina, Georgia, Macedonia, Moldova, Montenegro, Serbia, Russia, and Ukraine. The second group includes 'new' EU member states, i.e. countries that joined the EU in or after 2004: Bulgaria, Croatia, the Czech Republic, Estonia, Hungary, Latvia, Lithuania, Malta, Poland, Romania, Slovakia, and Slovenia. The third group comprises established Western European democracies, i.e. countries that were members of the European Union or the European Free Trade Association before 2004: Austria, Belgium, Denmark, Finland, France, Germany, Greece, Ireland, Iceland, Italy, Luxembourg, the Netherlands, Norway, Portugal, Spain, Sweden, Switzerland, and the United Kingdom. In descriptive analyses the latter group - the 'old' EU countries - is additionally divided into Northern Europe and Western Europe to improve the presentation of the results.

\section{Control variables}

The analysis also adjusts for a number of individual-level characteristics that potentially affect political trust: age, sex, education, and economic status. Age and sex tend to be weakly associated with political trust and are included for comparative purposes. To facilitate estimation, age in years is divided by 10 . Education is measured as the number of years of schooling the respondent has completed, derived from the age upon completion of full-time education. To avoid extreme values, the number of years of schooling was top-coded at 20, which corresponds to an advanced degree. The relationship between education and trust is known to depend on the country's level of democracy [Kołczyńska 2020] and corruption [Hakhverdian and Mayne 2012]. Since exploring the relative importance of country characteristics as moderators of the education-trust association is beyond the scope of this analysis, education is interacted with the region identifier to account for the differences in the direction of the effects across countries.

I include household income as a measure of economic status expecting that the well-off may be more supportive of the system that enabled them to achieve their privileged position. Despite some differences in the design of household income variables in WVS [Donnelly and Pop-Eleches 2018], the variable is ordinal in all national surveys, which satisfies the requirements of the present analysis. To improve comparability, the income scale was standardized within national surveys. Table A2 in the Appendix presents summary statistics for all variables. 


\section{Models}

The analysis consists of three-level linear regression models with individuals nested in country-years, nested in countries. The first set of models estimates the effects of macro-level indicators on political trust of individual $i$ in country $j$ and year $k$ without distinguishing between- and within-country variation:

$$
\begin{aligned}
& \text { trust }_{i j k}=\beta_{0}+\beta_{1} \text { newE } U_{j}+\beta_{2} \text { oldEU } U_{j}+\beta_{3} \text { macro indicator }_{j k}+\beta_{4} \text { year }_{j k}+\beta_{x} \text { controls }_{i j k}+ \\
& +e_{i j k}+r_{0 j k}+u_{00 k}
\end{aligned}
$$

where $\beta_{0}$ is the overall intercept, and the $\beta$-coefficients correspond to the fixed effects, $\beta_{1}$ and $\beta_{2}$, distinguishing between the 'new' and 'old' EU countries and the non-EU countries (reference category), while $\beta_{3}$ is the coefficient for the macrolevel indicator, $\beta_{4}$ captures the effect of time, and $\beta_{x}$ represents coefficients for the individual-level control variables. Finally, $e_{i j k}, r_{0 j k}$, and $u_{00 k}$ correspond to error terms at different levels. Because of the relatively strong correlations between the macro-level variables, they are entered into models separately. Next, each macrolevel measure is interacted with the country group dummies to see whether their effects vary between non-EU, 'new' EU, and 'old' EU countries.

In the second part of the analysis, the models distinguish the effects of between-country differences and within-country changes in macro-level characteristics by decomposing them into the time-invariant country means $x_{j}$, and the time-varying deviations from the mean $x_{i k}$, [Fairbrother 2014; Schmidt-Catran and Fairbrother 2016]. The resulting model has the following form:

$$
\begin{aligned}
& \text { trust }_{i j k}=\beta_{0}+\beta_{1} \text { newE } U_{j}+\beta_{2} \text { oldEU }_{j}+\beta_{3} \Delta \text { macro indicator } \\
& \\
& +\beta_{5} \text { year }_{j k}+\beta_{x} \overline{\text { controls }}_{i j k}+e_{i j k}+r_{0 j k}+u_{00 k}
\end{aligned}
$$

where $\beta_{3}$ is the coefficient for the time-varying component of macro-level characteristics $\beta_{4}$, is the coefficient for the time-invariant components, and the remainder of the model is unchanged.

The analyses use case weights as provided in the EVS and WVS datasets. Rounds 1-4 of EVS and 1-6 of WVS provided a single weighting variable, while in the EVS/5 the 'calibration weight' was used. In cases where sub-national samples and corresponding weights are available in the EVS (Bosnia-Hercegovina and United Kingdom), weights have been modified to reflect the population proportions between two sub-national samples.

To estimate the models I used the lmer command in the lme4 package [Bates et al. 2015] in R [R Core Team 2020], the emmeans package [Lenth 2019] to probe interactions, and the stargazer package [Hlavac 2018] for the tables. ${ }^{8}$ Given the ex-

\footnotetext{
${ }^{8}$ Many other R packages were used in the analysis: sirt [Robitzsch 2019] for the approximate invariance models, rio [Chan et al. 2018] to import and export data sets, tidyverse [Wickham et al. 2019] to clean and transform the data, vdem [Marquez 2019], WDI [Ar-
} 
ploratory character of the study, significance levels are interpreted in descriptive terms as the amount of uncertainty around point estimates rather than suggesting any binary decision about the presence or lack of a given effect.

\section{Results}

Trends in Political Trust in Europe, 1990-2019

Before presenting model results, I describe the trajectories of political trust in the period 1990-2019. Figure 1 presents the mean levels of the political trust index in countries included in the analysis in four groups: countries that are not (at the time of writing) members of the European Union, the 'new' EU Member States who joined in or after 2004, the 'old' EU/EFTA Member States, which are additionally differentiated into Western Europe and Northern Europe. For legibility, the plots only include means without the uncertainty around them. The graphs show considerable variation in the level of political trust, which - measured on a scale from 0 to 10 - varies between 2.5 in Bulgaria (2008) and Croatia (2017), and around 6.3 in Norway (2018), and Denmark (2008). Overall, political trust is the highest in Northern Europe, where it ranges from just above 4.5 to over 6 points. While individual countries have different trajectories, in the period between 1990 and 2019 this region generally saw an increase in political trust, with the exception of Iceland, which saw a decline in trust from close to 6 in 1999 to around 5 in 2017.

In Western Europe trust has also been relatively solid and stable and has generally remained in the range between 3.5 and 6 . The lowest trust levels have been noted in Greece and Italy, and the highest in Luxembourg and Switzerland.

Among the group of the 'new' EU Member States from Central and Eastern Europe, each country tells a different story. Poland, for example, had a mean trust level of 5.3 in 1990, ${ }^{9}$ which then fell to 4.2 in 1999 and since then has stabilised at levels slightly above 3.5. In Estonia, trust increased from around 4 in 1999 to just above 5 in 2019. Bulgaria and Hungary started in 1990 with similar levels of trust at just below 5, but after an initial decline trust in Hungary returned to its early levels, while in Bulgaria trust continued to decline and reached around 3 in 2017. In terms of overall tendencies, the region saw an increase in the dispersion of political trust, with the range increasing from between 4.1 and 5.3 in 1990 to between 2.5 and 5.1 .

el-Bundock 2019] to download democracy and economic indicators, and countrycode [Arel-Bundock, Enevoldsen, and Yetman 2018] to switch between country names and codes.

9 According to the WVS/2 survey, the mean trust level in Poland in 1989 was higher than 6, but this national survey was excluded due to the lack of GDP per capita data. Additionally, such high trust likely reflected hope and optimism about the future rather than any assessment of institutional performance thus far. 
Figure 1. Changes in political trust between 1990 and 2019
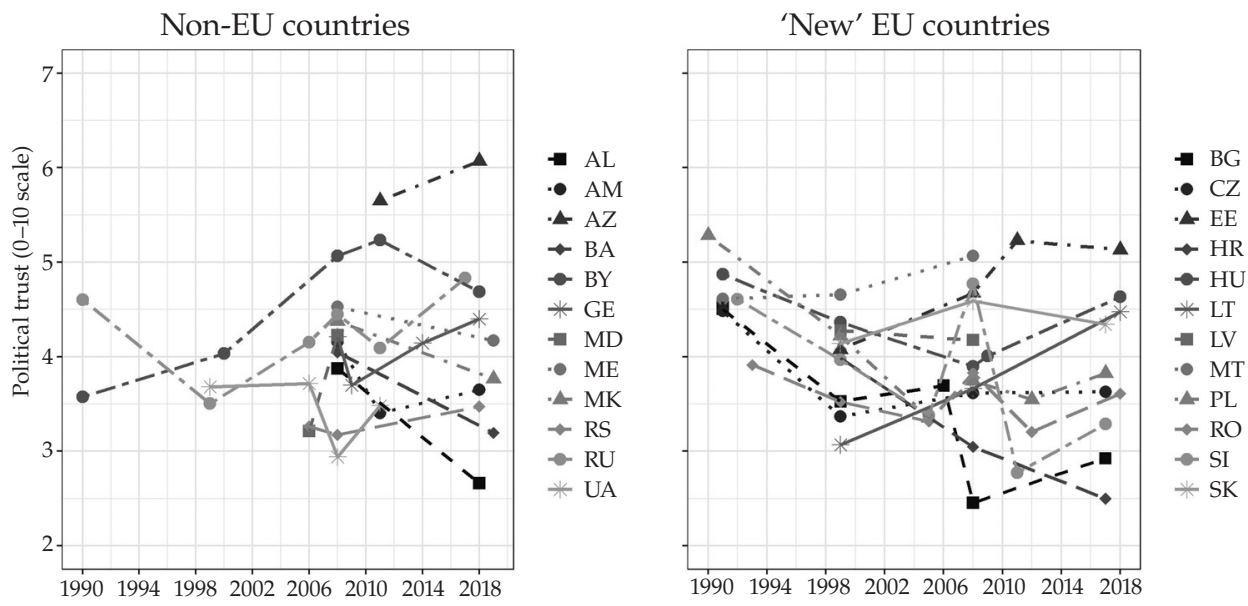

'Old' EU countries: Western Europe
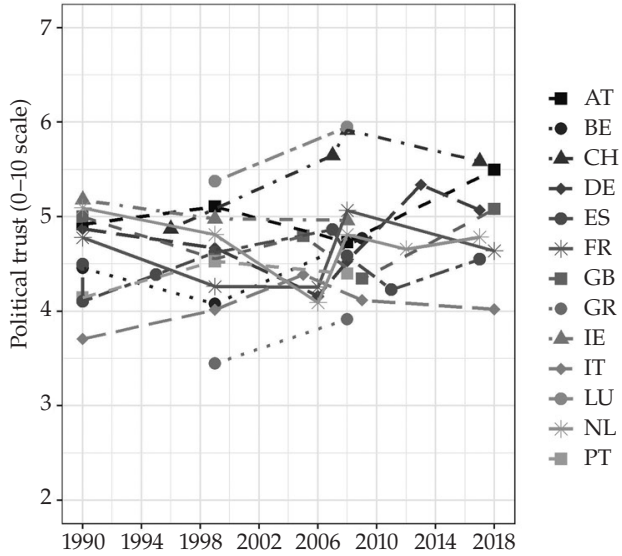

'Old' EU countries: Northern Europe

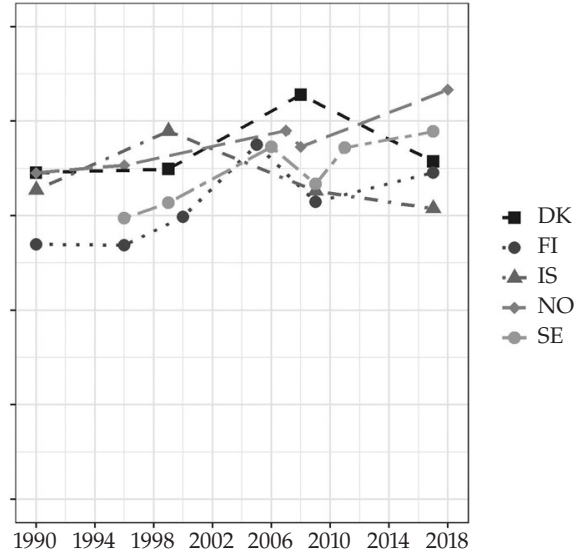

Note: $\mathrm{AL}=$ Albania, $\mathrm{AM}=$ Armenia, $\mathrm{AT}=$ Austria, $\mathrm{AZ}=$ Azerbaijan,

$\mathrm{BA}=$ Bosnia-Herzegovina, $\mathrm{BE}=$ Belgium, $\mathrm{BG}=$ Bulgaria, $\mathrm{BY}=$ Belarus,

$\mathrm{CH}=$ Switzerland, $\mathrm{CZ}=$ Czech Republic, $\mathrm{DE}=$ Germany, $\mathrm{DK}=$ Denmark,

$\mathrm{EE}=$ Estonia, $\mathrm{ES}=$ Spain, FI = Finland, FR = France, GB = United Kingdom,

$\mathrm{GE}=$ Georgia, $\mathrm{GR}=$ Greece, $\mathrm{HR}=$ Croatia, $\mathrm{HU}=$ Hungary, $\mathrm{IE}=$ Ireland, $\mathrm{IS}=$ Iceland,

$\mathrm{IT}=$ Italy, LT = Lithuania, LU = Luxembourg, LV = Latvia, MD = Moldova,

$\mathrm{ME}=$ Montenegro, $\mathrm{MK}=$ North Macedonia, $\mathrm{MT}=$ Malta, $\mathrm{NL}=$ the Netherlands,

$\mathrm{NO}=$ Norway, PL = Poland, PT = Portugal, $\mathrm{RO}=$ Romania, $\mathrm{RS}=$ Serbia, RU = Russia,

$\mathrm{SE}=$ Sweden, $\mathrm{SI}=$ Slovenia, $\mathrm{SK}=$ Slovakia, $\mathrm{UA}=$ Ukraine . 
A similarly dynamic picture emerges from the examination of the trust trends among non-EU countries from Eastern and South-Eastern Europe and the Caucasus. Most of these countries did not participate in the earlier rounds of EVS or WVS in the 1990s, with the exception of Belarus and Russia, for which data are available starting from 1990, and Ukraine, which joined in 1999. The highest levels of trust have been noted in Azerbaijan, just over 6 in 2018, a level similar to that in Northern Europe. In the remaining non-EU countries, average trust levels and their volatility make them similar to the 'new' EU countries.

\section{Trust, economic performance, and quality of governance: total effects}

Before presenting the results of the conditional multi-level linear regression models, a few words about variance decomposition are in order. As Table A3 shows, between-country differences account for some $10 \%$ of the total variation in political trust, differences between surveys carried out in the same country in different years account for just over $4 \%$ of the total variation, and the remaining $86 \%$ is between individuals. ${ }^{10}$ It is worth realising that macro-level characteristics address just $14 \%$ of trust's total variation. A high proportion of individual-level variance is typical for analyses of political attitudes. A study of attitudes towards immigration in Europe [Meuleman, Davidov and Billiet 2018] using the European Social Survey $2002-2012$ found $7.5 \%$ and $12.5 \%$ of between-country variance to be attributable to economic and cultural threat, respectively and only $2 \%$ and $0.9 \%$ between country-years. Compared to this, political trust is more volatile, as indicated by the higher share of variance between country-years.

Conditional models regress political trust on measures of institutional functioning, with separate models per macro-level variable. The first set of models includes an overall effect of each macro-level characteristic, while the second set of models adds interactions between each macro-level characteristic and regional identifiers. Table 1 presents the estimated effects for the entire set of countries, and for non-EU, 'new' EU, and 'old' EU countries separately. The full model results are presented in the Appendix (Tables A5 and A6).

According to the results in Table 1 for Europe as a whole (Models 1.1-1.5), political trust is positively associated with GDP per capita and negatively with corruption and unemployment. These results are consistent with the expectation that political trust constitutes a reward for good performance. At the same time, contrary to expectations, higher electoral democracy scores are associated with lower political trust.

To determine whether these average effects of macro-level characteristics

\footnotetext{
${ }_{10}$ The share of between-country variance has been steadily increasing in consecutive waves of the EVS, from 5\% in EVS/2, to 10\% in EVS/3, 14\% in EVS/4, and 19\% in EVS/5, as country means have become more dispersed, particularly in Central and Eastern European countries, which we can see in Figure 1.
} 
Table 1. Political trust and macro-level indicators for all of Europe and by region

\begin{tabular}{lcccc}
\hline & Models 1.1-1.5 & \multicolumn{3}{c}{ Models 2.1-2.5 } \\
\cline { 2 - 5 } Macro-level indicator & All countries & Non-EU & 'New' EU & 'Old' EU \\
\hline GDP per capita & $0.276^{*}$ & $0.756^{*}$ & 0.082 & $0.299^{*}$ \\
(10 000 USD) & $(0.07)$ & $(0.234)$ & $(0.122)$ & $(0.073)$ \\
Unemployment & $-3.122^{*}$ & -1.96 & -1.51 & $-5.83^{*}$ \\
& $(1.183)$ & $(1.78)$ & $(2.35)$ & $(2.01)$ \\
Public sector & $-0.757^{*}$ & -0.288 & -0.614 & $-4.355^{*}$ \\
corruption (V-Dem) & $(0.42)$ & $(0.573)$ & $(0.603)$ & $(1.307)$ \\
Bayesian Corruption & $-3.684^{*}$ & -2.98 & $-3.84^{*}$ & $-3.83^{*}$ \\
Indicator (QOG) & $(0.668)$ & $(1.565)$ & $(1.39)$ & $(0.887)$ \\
Democracy (V-Dem) & $-2.291^{*}$ & $-2.752^{*}$ & $-1.949^{*}$ & -0.534 \\
& $(0.524)$ & $(0.776)$ & $(0.742)$ & $(2.883)$ \\
\hline
\end{tabular}

Note: Standard errors in parentheses. ${ }^{*} \mathrm{p}<0.05$. Data source: European Values Study waves 2-5, World Values Survey waves 2, 3, 5, 6, World Bank, Varieties of Democracy, Quality of Government Institute.

hold across Europe or are primarily driven by a group of countries, Models 2.1-2.5 add interactions between country groups and the macro-level variables. The results show that the overall association between trust and GDP per capita is primarily driven by non-EU countries and the 'old' EU, while in the 'new' EU countries the association is negligible. On the other hand, unemployment exhibits the largest effect on trust in the 'old' EU, where an increase in unemployment by 10 percentage points is associated with a drop in trust by around 0.6. In the other regions the effects are weaker but also negative.

Public sector corruption (V-Dem) also reveals the strongest link to trust in the 'old' EU countries, where a one-unit change in corruption (corresponding to the theoretical range of the variable) is associated with a decline in trust by almost 4.5 units on the 0-10 trust scale. In the 'new' EU and non-EU countries the association between trust and corruption is also negative, but several times weaker. The results are different when looking at the QOG Bayesian Corruption Indicator. Here, the association between corruption and trust is similarly strong in the 'new' and 'old' EU, and somewhat weaker in the non-EU countries. Finally, political trust turns out to be negatively associated with the level of democracy in all regions, with the effect much stronger in the 'new' and non-EU countries compared to the 'old' EU.

Overall, these results reveal differences in the effects of macro-level characteristics indicators between European regions, but these differences are in the magnitude and noisiness of the effect, not in the direction, which in all cases except the democracy scores is in line with theoretical expectations. 
Trust, economic performance, and quality of governance: between- and within-country effects

The next part of the analysis distinguishes between time-invariant components (the mean within countries) and time-varying components (deviation from that mean) of economic performance and the quality of governance. As in the previous part, Table 2 presents only the coefficients of interest, while the full model results are available in the Appendix (Tables A7 and A8).

The first column in Table 2 (Models 3.1-3.5) presents results for all countries together. They show that the positive effect of GDP per capita on trust observed earlier is both due to between-country and within-country variation in development. In other words, countries that on average have higher GDP per capita enjoy higher political trust, but also as GDP per capita increases, trust - on average - goes up as well. The situation is similar for unemployment, where both the within- and between-country coefficients have negative signs.

The situation with corruption is less straightforward. When comparing between countries, those with more corruption tend to have less trusting citizens, as theory would predict. This result is the same for both measures of corruption. However, the association of within-country changes in corruption and political trust yields different results depending on the corruption indicator. When relying on the V-Dem measure, the association is positive, which would mean that, on average, as countries become more corrupt, the level of political trust increases. According to the QOG corruption indicator, the longitudinal association remains negative, but weaker than the coefficient for between-country corruption.

Regarding the quality of democracy, both the within- and the betweencountry coefficients are negative, indicating that as democracy improves, trust declines, and that, on average, less democratic countries see higher political trust. The between-country coefficient is much smaller than the within-country coefficient.

The remaining columns of Table 2 present estimated effects of state functioning in three European regions, based on Models 4.1-4.5 (Table A8 in the Appendix). According to these results, the between-country effect of GDP per capita is similarly strong in all regions, but with different amounts of uncertainty. The within-country effect of changes in GDP per capita are the strongest in the nonEU countries, weaker in the 'old' EU countries, and weak in the 'new' EU countries. Thus, according to the model, a unit increase (i.e. by 10000 USD, observed, for example, between 2009 and 2019 in Poland), in GDP per capita is associated with an increase in political trust by 0.17 in the 'new' EU countries, by 0.47 in the 'old' EU countries, and in the non-EU countries by more than 1 unit on the $0-10$ trust scale. Unemployment also has consistent effects across all regions, in a negative direction, and this observed in the case of both between- and withincountry differences, with the strongest effects seen in the 'old' EU member states.

The negative between-country associations between corruption and trust 
Table 2. Political trust and macro-level indicators of within- and between-country effects for all of Europe and by region

\begin{tabular}{|c|c|c|c|c|}
\hline \multirow[b]{2}{*}{$\begin{array}{l}\text { Macro-level } \\
\text { indicator }\end{array}$} & \multirow{2}{*}{$\begin{array}{l}\text { Models 3.1-3.5 } \\
\text { All countries }\end{array}$} & \multicolumn{3}{|c|}{ Models 4.1-4.5 } \\
\hline & & Non-EU & 'New' EU & ‘Old' EU \\
\hline \multirow{2}{*}{$\begin{array}{l}\text { GDP per capita: } \\
\text { time-invariant }\end{array}$} & $0.252^{*}$ & 0.416 & 0.381 & $0.239^{*}$ \\
\hline & $(0.080)$ & $(0.394$ & $(0.344)$ & $(0.086)$ \\
\hline \multirow{2}{*}{$\begin{array}{l}\text { GDP per capita: } \\
\text { time-varying }\end{array}$} & $0.346^{*}$ & $1.054^{*}$ & 0.173 & $0.47^{*}$ \\
\hline & $(0.134)$ & $(0.301$ & $(0.152)$ & $(0.138)$ \\
\hline \multirow{2}{*}{$\begin{array}{l}\text { Unemployment: } \\
\text { time-invariant }\end{array}$} & $-4.557^{*}$ & -3.040 & -1.720 & $-9.4^{*}$ \\
\hline & $(2.033)$ & $(2.590$ & $(6.060)$ & $(4.060)$ \\
\hline \multirow{2}{*}{$\begin{array}{l}\text { Unemployment: } \\
\text { time-varying }\end{array}$} & $-2.427^{*}$ & -1.200 & -1.180 & -4.590 \\
\hline & $(1.456)$ & $(2.480$ & $(2.530)$ & $(2.350)$ \\
\hline \multirow{2}{*}{$\begin{array}{l}\text { Corruption (V-Dem): } \\
\text { time-invariant }\end{array}$} & $-1.268^{*}$ & 0.322 & $-1.644^{*}$ & $-4.267^{*}$ \\
\hline & $(0.510)$ & $(0.741$ & $(0.694)$ & $(1.311)$ \\
\hline \multirow{2}{*}{$\begin{array}{l}\text { Corruption (V-Dem): } \\
\text { time-varying }\end{array}$} & 0.340 & -1.460 & 1.760 & -5.250 \\
\hline & $(0.774)$ & (1.110 & (1.050) & $(5.410)$ \\
\hline \multirow{2}{*}{$\begin{array}{l}\text { Corruption (QOG): } \\
\text { time-invariant }\end{array}$} & $-3.960^{*}$ & -3.510 & $-3.76^{*}$ & $-4.13^{*}$ \\
\hline & $(0.748)$ & $(2.057$ & (1.693) & $(0.955)$ \\
\hline \multirow{2}{*}{$\begin{array}{l}\text { Corruption (QOG): } \\
\text { time-varying }\end{array}$} & -2.490 & -1.980 & -3.960 & -1.610 \\
\hline & $(1.590)$ & $(2.810$ & $(2.690)$ & $(2.610)$ \\
\hline \multirow{2}{*}{$\begin{array}{l}\text { Democracy: } \\
\text { time-invariant }\end{array}$} & -0.841 & $-4.08^{*}$ & $3.36^{*}$ & 8.190 \\
\hline & $(1.180)$ & $(1.360$ & (1.630) & $(6.390)$ \\
\hline \multirow{2}{*}{$\begin{array}{l}\text { Democracy: } \\
\text { time-varying }\end{array}$} & $-2.746^{*}$ & $-2.27^{*}$ & $-2.9^{*}$ & -2.150 \\
\hline & $(0.591)$ & $(0.943$ & $(0.795)$ & (3.145) \\
\hline
\end{tabular}

Note: Standard errors in parentheses. ${ }^{*} \mathrm{p}<0.05$. Data source: European Values Study waves 2-5, World Values Survey waves 2, 3, 5, 6, World Bank, Varieties of Democracy, Quality of Government Institute.

are the strongest in the 'old' EU,,$^{11}$ according to both corruption indicators, and are also negative and sizeable in the 'new' EU. In the non-EU countries, the between-country effect of corruption is found to be weakly positive when we use

\footnotetext{
${ }^{11}$ Compared to the non-EU and the 'new' EU countries, in the 'old' EU changes in both V-Dem indicators capturing corruption and democracy are very small, and the effects are in fact driven by a small number of countries that saw greater changes.
} 
the V-Dem measure and negative when employing the QOG indicator. Regarding the within-country effects of corruption, the coefficients are negative for both corruption indicators, with the exception of the strong positive coefficient in the 'new' EU countries that is observed when the V-Dem Public Corruption Index is used. $^{12}$

Democracy is another case where the between- and within-country effects are different. When comparing between countries, the association with trust is positive in the 'new' and 'old' EU countries and negative in the non-EU group. The within-country effects of democracy are negative in all regions.

\section{Summary and conclusion}

The association between economic performance and the quality of governance with political trust may seem straightforward. According to theory, insofar as trust is understood as an evaluation of the political system and its institutions, higher levels of ability and integrity would be associated with more trust in state institutions among citizens. In this paper I analysed the association between political trust and different dimensions of state functioning in 42 European countries between 1990 and 2019. The results overall point to associations between the economic aspects of state performance - GDP per capita and employment - and trust in the expected directions, with some variation in the magnitude of the effects across regions and generally the strongest and clearest associations in the 'old' EU, i.e. in the established democracies in Western Europe.

The puzzling result deals with the role of corruption and democracy, i.e. the integrity- and benevolence-related dimensions of state functioning. In the case of public sector corruption, measured with the V-Dem index, between-country associations with political trust are negative in the 'old' and the 'new' EU member states and are weakly positive among non-EU countries. When looking at the within-country effect, the 'new' EU countries stand out for the strong positive association that is found there between corruption and trust.

Interestingly, when using the QOG Bayesian Corruption Indicator, the patterns of associations are more consistent with the theoretical performance-trust link, and the associations between corruption and trust are always negative. To the extent that the BCI measures public perceptions of corruption contrasted with expert assessments used to construct the V-Dem indicator, it seems to be the more appropriate measure of corruption in the present analysis. However, the discrepancies between the two corruption indicators are surprisingly large, and a more

${ }^{12}$ QOG Corruption scores are not available for some Central and Eastern European countries for 1990 and 1991. However, even after eliminating surveys without QOG scores from the models with the V-Dem corruption indicator, the same anomalous corruption-trust association persists. 
thorough analysis of their source data and estimation methods could shed light on the reasons for the differences in the trust-corruption association, both in substantive and methodological terms.

At the same time, in all regions the association between within-country changes in the quality of electoral democracy and trust is negative. In Central Europe, the negative association between political trust and democracy could be interpreted as stemming from the 'post-honeymoon' and transition fatigue in the 1990s, at a time when democracy was improving. More recently, trust increased in Hungary in the 2010s as the country was taking an illiberal turn under Victor Orbán. Among the non-EU countries, in Belarus and Russia, for example, trust was increasing as democracy was deteriorating, possibly in reaction to the improved stability and predictability of the state under authoritarian rule. These examples question the presence of an unconditional link between political trust and democratic legitimacy, with overall stability and satisfactory economic conditions being likely conditions for the trust-democracy link to emerge. In the 'old' EU, the observed negative association between trust and democracy likely stems from the overall small changes in the quality of democracy as measured by the V-Dem indicator, which makes the coefficient unstable, as indicated by the large standard error.

The links between state performance and governance and political trust warrant further research in several directions. First, it is possible that the functional form of the relationship between macro-level performance and political trust in a longitudinal perspective is much more complex than the linear associations assumed in the models. Trust may be shaped by the experience of a state's performance accumulated over extended periods of time, it may exhibit threshold effects, or it may react differently to positive and to negative performance changes. Second, when forming an assessment of state trustworthiness different people may assign a different weight to various aspects of performance, and systematic comparisons across societal groups may elucidate these processes.

Further, if citizens respond to performance and governance by adjusting their political trust, there may be a disconnect between perceptions and reality. Empirical studies are quite unanimous with regard to the positive association between subjective performance evaluations and political trust, where sociotropic evaluations of the economy matter more for political trust than evaluations of one's own economic situation do [van der Meer 2017]. Some of the disconnect between objective and perceived performance and governance may be due to limited or unequal access to information about macro-level performance if, for instance, there is selective media coverage of only certain events. For example, research suggests that what matters the most for political trust is the perceived responsiveness of the state [Torcal 2014], which macro-level indicators may not capture well.

Another issue deals with the measurement of trust. This article relied on a unidimensional conceptualisation of trust in institutions and focused on the mean 
level of trust, while researchers are increasingly interested in the type or content of political trust. For example, Wu and Wilkes [2018] distinguish between 'critical trusters', who demonstrate different levels of trust in different institutions, 'compliants' who exhibit high trust in all institutions, and 'cynics', who distrust all. Their study found, among others, that the proportion of critical trusters is the highest in full democracies compared to flawed democracies and hybrid regimes and is the lowest in authoritarian regimes. Such approaches may solve some of the puzzles surrounding the links between trust, performance, and governance.

In terms of data limitations, while the combined EVS and WVS data set provides repeated measurements in most European countries over the last three decades, the surveys are only carried out approximately every 9 years. Given that political trust tends to be rather volatile and may react to short-term fluctuations in performance and its perceptions, surveys with such long intervals are not ideally suited for studying it. For example, data from the EVS in 2008 and in 2018 may have missed the decline in political trust following the global financial crisis [cf. Kołczyńska et al. 2020]. Further, with few measurements for each country, if even a few surveys have poor data quality, resulting in biased mean estimates of political trust, the analysis may be compromised. The ex-post harmonisation of data from different survey project can mitigate this issue, but requires that the complications that arise from jointly analysing survey data of varying quality collected using different methodologies first be addressed. By highlighting the sensitivity of the results depending on the choice of the corruption indicator, this study also points to the challenges associated with constructing macro-level indicators suitable for longitudinal comparisons.

At least one finding of this study is unambiguously reassuring. Despite the widespread concern with the future of democracy following the decline in political trust in the United States and Western Europe that began in the 1960s, in the last three decades political trust in most European countries has been fluctuating without a clear trend. No consistent erosion of this form of political support has been observed in established democracies in particular [Norris 2011]. At the same time, many of the post-communist and now 'new' EU countries have experienced a substantial decline in political trust since the 1990s, and it is unclear if the next years will bring a correction to this tendency.

MARTA KoŁCZYŃSKa holds a PhD in sociology from the Ohio State University and works at the Institute for Political Studies of the Polish Academy of Sciences. Her research focuses on the causes and consequences of political attitudes and polarisation and crossnational survey methodology. Her work has appeared in journals such as the International Journal of Comparative Sociology, International Journal of Public Opinion Research, and Methodology. 


\section{References}

Arel-Bundock, V. 2019. 'WDI: World Development Indicators (World Bank).' Retrieved 15 June 2020 (https: //cran.r-project.org/package=WDI).

Arel-Bundock, V., N. Enevoldsen and C. J. Yetman. 2018. 'Countrycode: An R Package to Convert Country Names and Country Codes.' Journal of Open Source Software 3 (28): 848, https://doi.org/10.21105/joss.00848.

Asparouhov, T. and B. Muthén. 2014. 'Multiple-Group Factor Analysis Alignment.' Structural Equation Modeling: A Multidisciplinary Journal 21: 495-508, https://doi.org/10.1080/10705511.2014.919210.

Barber, B. 1983. The Logic and Limits of Trust. New Brunswick, NJ: Rutgers University Press.

Bargsted, M., N. M. Somma and J. Carlos Castillo. 2017. 'Political Trust in Latin America.' Pp. 395-417 in Handbook on Political Trust. Cheltenham: Edward Elgar Publishing, https:// doi.org/10.4337/9781782545118.00036.

Bates, D., M. Mächler, B. Bolker and S. Walker. 2015. 'Fitting Linear Mixed-Effects Models Using Lme4.' Journal of Statistical Software 67 (1): 1-48, https://doi.org/10.18637/jss.v067.i01.

Bauer, P. C. 2018. 'Unemployment, Trust in Government, and Satisfaction with Democracy: An Empirical Investigation.' Socius: Sociological Research for a Dynamic World 4: 1-14, https://doi.org/10.1177/2378023117750533.

Bratton, M. and R. Mattes. 2001. 'Support for Democracy in Africa: Intrinsic or Instrumental?' British Journal of Political Science 31 (3): 447-474, https://doi.org/10.1017/S0007123401000175.

Brehm, J. and W. Rahn. 1997. 'Individual-Level Evidence for the Causes and Consequences of Social Capital.' American Journal of Political Science 41 (3): 999-1023, https://doi.org/10.2307/2111684.

Breustedt, W. 2017. 'Testing the Measurement Invariance of Political Trust across the Globe. A Multiple Group Confirmatory Factor Analysis.' Methods, Data, Analyses 12 (1): 1-39. https://doi.org/10.12758/mda.2017.06.

Catterberg, G. 2013. 'Intergenerational Value Change and Transitions to Democracy. Toward the Consolidation of a Third Wave Generation?' Revista Latinoamericana de Opinión Pública 3: 53-80.

Catterberg, G. and A. Moreno. 2006. 'The Individual Bases of Political Trust: Trends in New and Established Democracies.' International Journal of Public Opinion Research 18 (1): 31-48, https://doi.org/10.1093/ijpor/edh081.

Chan, C.-H., G. C. H. Chan, T. J. Leeper and J. Becker. 2018. ‘Rio: A Swiss-Army Knife for Data File I/O.' Retrieved 15 June 2020 (https://cloud.r-project.org/web/packages/rio/index.html).

Coppedge, M., J. Gerring, C. H. Knutsen, S. I. Lindberg, J. Teorell, D. Altman, M. Bernhard, M. S. Fish, A. Glynn, A. Hicken, A. Lührmann, K. L. Marquardt, K. McMann, P. Paxton, D. Pemstein, B. Seim, R. Sigman, S.-E. Skaaning, J. Staton, S. Wilson, A. Cornell, N. Alizada, L. Gastaldi, H. Gjerløw, G. Hindle, N. Ilchenko, L. Maxwell, V. Mechkova, J. Medzihorsky, J. von Römer, A. Sundström, E. Tzelgov, Y. Wang, T. Wig and D. Ziblatt. 2020. 'V-Dem Country-Year Dataset V10.' https://doi.org/https://doi.org/10.23696/vdemds20.

Coppedge, M., J. Gerring, C. H. Knutsen, S. I. Lindberg, J. Teorell, D. Altman, M. Bernhard, M. S. Fish, A. Glynn, A. Hicken, A. Lührmann, K. L. Marquardt, K. McMann, P. Paxton, D. Pemstein, B. Seim, R. Sigman, S.-E. Skaaning, J. Staton, S. Wilson, A. Cornell, L. Gastaldi, H. Gjerløw, N. Ilchenko, J. Krusell, L. Maxwell, V. Mechkova, J. Medzihorsky, J. Pernes, J. von Römer, N. Stepanova, A. Sundström, 
E. Tzelgov, Y. Wang, T. Wig and D. Ziblatt. 2019. V-Dem Codebook V9.

https://www.v-dem.net/en/reference/version-9-apr-2019/, https://doi.org/10.2139/ssrn.3441060.

Craig, S. C., R. G. Niemi and G. E. Silver. 1990. 'Political Efficacy and Trust: A Report on the NES Pilot Study Items.' Political Behavior 12 (3): 289-314, https://doi.org/10.1007/BF00992337.

Criado, H. and F. Herreros. 2007. 'Political Support.' Comparative Political Studies 40 (12): 1511-1532, https://doi.org/10.1177/0010414006292117.

Dahlberg, S., S. Holmberg, B. Rothstein, N. Alvarado Pachon and S. Axelsson. 2020. 'The Quality of Government Basic Dataset.' https://doi.org/10.18157/qogbasjan20.

Dalton, R. J. 2004. Democratic Challenges, Democratic Choices: The Erosion of Political Support in Advanced Industrial Democracies. Oxford: Oxford University Press, https://doi.org/10.1093/acprof:oso/9780199268436.003.0008.

Dalton, R., A. Van Sickle and S. Weldon. 2010. 'The Individual-Institutional Nexus of Protest Behaviour.' British Journal of Political Science 40 (1): 51-73, https://doi.org/10.1017/S000712340999038X.

Darden, K. and A. Grzymala-Busse. 2006. 'The Great Divide: Literacy, Nationalism, and the Communist Collapse.' World Politics 59 (1): 83-115, https://doi.org/10.1353/wp.2007.0015.

Davis, D. W. and B. D. Silver. 2004. 'Civil Liberties v. Security: Public Opinion in the Context of the Terrorist Attacks on America.' American Journal of Political Science 48 (1): 28-46, https:// doi.org/10.1111/j.0092-5853.2004.00054.x.

Donnelly, M. J. and G. Pop-Eleches. 2018. 'Income Measures in Cross-National Surveys: Problems and Solutions.' Political Science Research and Methods 6 (2): 355-363, https://doi.org/10.1017/psrm.2016.40.

Easton, D. 1965. A Systems Analysis of Political Life. New York: Wiley.

Easton, D. 1975. 'A Re-assessment of the Concept of Political Support.' British Journal of Political Science 5 (4): 435-457, https://doi.org/10.1017/S0007123400008309.

Van Erkel, P. F. A. and T. W. G. Van der Meer. 2016. 'Macroeconomic Performance, Political Trust and the Great Recession: A Multilevel Analysis of the Effects of withinCountry Fluctuations in Macroeconomic Performance on Political Trust in 15 EU Countries, 1999-2011.' European Journal of Political Research 55 (1): 177-197, https://doi.org/10.1111/1475-6765.12115.

European Values Study. 2015. 'European Values Study Longitudinal Data File 1981-2008 (EVS 1981-2008). ZA4804 Data File Version 3.0.0.'

European Values Study. 2018. European Values Study Master Questionnaire 2017. Final Vers. Cologne: GESIS Data Archive.

Fairbrother, M. 2014. 'Two Multilevel Modeling Techniques for Analyzing Comparative Longitudinal Survey Datasets.' Political Science Research and Methods 2 (1): 119-140, https://doi.org/10.1017/psrm.2013.24.

Freedom House. 2020. 'Freedom in the World. Country and Territory Ratings and Statuses, 1973-2020.' Retrieved 15 June 2020 (https://freedomhouse.org/sites / default/files/2020-02/2020_Country_and_Territory_Ratings_and_Statuses_FIW19732020.xlsx).

Gedeshi, I., S. Kritzinger, G. Poghosyan, D. Rotman, M. Pachulia, G. Fotev, J. KolenovićĐapo, L. Rabušic, J. Baloban, M. Frederiksen, E. Saar, K. Ketola, C. Wolf, M. Pachulia, P. Bréchon, D. Voas, G. Rosta, G. A. Jónsdóttir, G. Rovati, R. Ziliukaite, A. Petkovska, O. Komar, T. Reeskens, A. T. Jenssen, N. Soboleva, M. Marody, B. Voicu, K. Strapcová, M. Bešić, S. Uhan, M. Silvestre Cabrera, S. Wallman-Lundåsen and M. E. Stähli. 2020. 'European Values Study 2017: Integrated Dataset (EVS 2017).'

https://doi.org/doi:10.4232/1.13511. 
Hakhverdian, A. and Q. Mayne. 2012. 'Institutional Trust, Education, and Corruption: A Micro-Macro Interactive Approach.' The Journal of Politics 74 (3): 739-750, https://doi.org/10.1017/S0022381612000412.

Hamm, J. A., C. Smidt and R. C. Mayer. 2019. 'Understanding the Psychological Nature and Mechanisms of Political Trust.' PLOS ONE 14 (5): e0215835, https://doi.org/10.1371/journal.pone.0215835.

Hardin, R. 2002. Trust and Trustworthiness. New York: Russell Sage Foundation.

Hlavac, M. 2018. 'Stargazer: Well-Formatted Regression and Summary Statistics Tables.' Retrieved 15 July 2020 (https://cran.r-project.org/package=stargazer).

Hooghe, M. 2011. 'Why There Is Basically Only One Form of Political Trust.' British Journal of Politics and International Relations 13 (2): 269-275, https://doi.org/10.1111/j.1467-856X.2010.00447.x.

Inglehart, R. F., C. Haerpfer, A. Moreno, C. Welzel, K. Kizilova, J. Diez-Medrano, M. Lagos, P. Norris, E. Ponarin and B. Puranen. 2014. 'World Values Survey: All Rounds - Country-Pooled Datafile 1981-2014.' Retrieved 20 July 2020 (http://www.worldvaluessurvey.org/WVSDocumentationWVL.jsp).

Kasperson, R. E., D. Golding and S. Tuler. 1992. 'Social Distrust as a Factor in Siting Hazardous Facilities and Communicating Risks.' Journal of Social Issues 48 (4): 161-187, https://doi.org/10.1111/j.1540-4560.1992.tb01950.x.

Kaufmann, D., A. Kraay and M. Mastruzzi. 2010. 'The Worldwide Governance Indicators: Methodology and Analytical Issues.' World Bank Policy Research Working Paper 5430.

Klingemann, H.-D. 1999. 'Mapping Political Support in the 1990s.' Pp. 31-56 in Critical Citizens: Global Support for Democratic Governance, edited by P. Norris. Oxford: Oxford University Press, https://doi.org/10.1093/0198295685.003.0002.

Kołczyńska, M. 2020. 'Democratic Values, Education, and Political Trust.' International Journal of Comparative Sociology 61 (1): 3-26, https://doi.org/10.1177/0020715220909881.

Kołczyńska, M. and P.-C. Bürkner. 2020. 'Marketplace of Indicators: Inconsistencies between Country Trends of Measures of Governance.' SocArXiv, 6 September, https://doi.org/10.31235/osf.io/u8gsc.

Kołczyńska, M., P.-C. Bürkner, L. Kennedy and A. Vehtari. 2020. 'Trust in State Institutions in Europe, 1989-2019.' SocArXiv, 11 August, https://doi.org/10.31235/osf.io/3v5g7.

Kroknes, V. F., T. G. Jakobsen and L.-M. Grønning. 2015. 'Economic Performance and Political Trust: The Impact of the Financial Crisis on European Citizens.' European Societies 17 (5): 700-723, https://doi.org/10.1080/14616696.2015.1124902.

Lenth, R. 2019. 'Emmeans: Estimated Marginal Means, Aka Least-Squares Means.' Retrieved 15 June 2020 (https://cran.r-project.org/package=emmeans).

Letki, N. 2007. 'Institutional Performance.' Pp. 457-458 in Encyclopedia of Governance, edited by M. Bevir. Thousand Oaks: SAGE Publications.

Lewis-Beck, M. S. 1988. Economics and Elections: The Major Western Democracies. Ann Arbor, MI: University of Michigan Press.

Listhaug, O. and M. Wiberg. 1995. 'Confidence in Political and Private Institutions.' Pp. 298-322 in Citizens and the State: Changing Public Attitudes toward Government in Western Europe, edited by H. D. Klingemann and D. Fuchs. Oxford and New York: Oxford University, https://doi.org/10.1093/0198294735.003.0010.

Lueders, H. and E. Lust. 2018. 'Multiple Measurements, Elusive Agreement, and Unstable Outcomes in the Study of Regime Change.' The Journal of Politics 80 (2): 736-741, https:// doi.org/10.1086/696864, https://doi.org/10.1086/696864. 
Marien, S. and M. Hooghe. 2011. 'Does Political Trust Matter? An Empirical Investigation into the Relation between Political Trust and Support for Law Compliance.' European Journal of Political Research 50 (2): 267-291, https://doi.org/10.1111/j.1475-6765.2010.01930.x.

Marquez, X. 2019. 'Vdem: Access to the Varieties of Democracy (V-Dem) Dataset.' Retrieved 15 June 2020 (https://github.com/xmarquez/vdem).

Mayer, R. C., J. H. Davis and F. D. Schoorman. 1995. 'An Integrative Model of Organizational Trust.' The Academy of Management Review 20 (3): 709, https://doi.org/10.2307/258792.

McAllister, I. 1999. 'The Economic Performance of Governments.' Pp. 188-203 in Critical Citizens: Global Support for Democratic Governance, edited by P. Norris. Oxford: Oxford University Press, https://doi.org/10.1093/0198295685.003.0009.

van der Meer, T. 2010. 'In What We Trust? A Multi-Level Study into Trust in Parliament as an Evaluation of State Characteristics.' International Review of Administrative Sciences 76 (3): 517-536, https://doi.org/10.1177/0020852310372450.

van der Meer, T. W. G. 2017. Economic Performance and Political Trust. Vol. 1, edited by E. M. Uslaner. New York, NY: Oxford University Press, https://doi.org/10.1093/oxfordhb/9780190274801.013.16.

van der Meer, T. W.G. and S. Zmerli. 2017. 'The Deeply Rooted Concern with Political Trust.' Pp. 1-16 in Handbook on Political Trust, edited by S. Zmerli and T. W. G. van der Meer. Cheltenham: Edward Elgar Publishing, https://doi.org/10.4337/9781782545118.00010.

Meuleman, B., E. Davidov and J. Billiet. 2018. 'Modeling Multiple-Country Repeated Cross-Sections. A Societal Growth Curve Model for Studying the Effect of the Economic Crisis on Perceived Ethnic Threat.' 12 (2): 185-209. https://doi.org/10.12758/mda.2017.10.

Miller, A. H. 1974. 'Political Issues and Trust in Government: 1964-1970.' American Political Science Review 68 (3): 951-972, https://doi.org/10.2307/1959140.

Miller, A. and O. Listhaug. 1999. 'Political Performance and Institutional Trust.' Pp. 204-216 in Critical Citizens. Global Support for Democratic Government, edited by P. Norris. Oxford University Press, https://doi.org/10.1093/0198295685.003.0010.

Miller, S. 2017. Institutional Corruption. Cambridge: Cambridge University Press, https://doi.org/10.1017/9781139025249.

Mishler, W. and R. Rose. 1997. 'Trust, Distrust and Skepticism: Popular Evaluations of Civil and Political Institutions in Post-Communist Societies.' The Journal of Politics 59 (2): 418-451, https://doi.org/10.1017/S0022381600053512.

Mishler, W. and R. Rose. 2001a. 'Political Support for Incomplete Democracies.' International Political Science Review 22 (4): 303-320, https://doi.org/10.1177/0192512101022004002.

Mishler, W. and R. Rose. 2001b. 'What Are the Origins of Political Trust? Testing Institutional and Cultural Theories in Post-Communist Societies.' Comparative Political Studies 34 (1): 30-62, https:// doi.org/10.1177/0010414001034001002.

Morlino, L. and M. Quaranta. 2014. 'The Non-Procedural Determinants of Responsiveness.' West European Politics 37 (2): 331-360, https://doi.org/10.1080/01402382.2014.887878.

Muro, D. and G. Vidal. 2017. 'Political Mistrust in Southern Europe since the Great Recession.' Mediterranean Politics 22 (2): 197-217, https://doi.org/10.1080/13629395.2016.1168962.

Norris, P. 1999. 'Introduction: The Growth of Critical Citizens?' Pp. 1-28 in Critical Citizens: Global Support for Democratic Government, edited by P. Norris. Oxford University Press, https://doi.org/10.1093/0198295685.003.0001. 
Norris, P. 2002. Democratic Phoenix: Reinventing Political Activism. Cambridge: Cambridge University Press, https://doi.org/10.1017/CBO9780511610073.

Norris, P. 2011. Democratic Deficit: Critical Citizens Revisited. Cambridge: Cambridge University Press, https://doi.org/10.1017/CBO9780511973383.

Oksanen, A., M. Kaakinen, R. Latikka, I. Savolainen, N. Savela and A. Koivula. 2020. 'Regulation and Trust: 3-Month Follow-Up Study on COVID-19 Mortality in 25 European Countries.' JMIR Public Health and Surveillance 6 (2): e19218, https://doi.org/10.2196/19218.

Pop-Eleches, G. and J. A. Tucker. 2011. 'Communism's Shadow: Postcommunist Legacies, Values, and Behavior.' Comparative Politics 43 (4): 379-408, https://doi.org/10.5129/001041511796301588.

della Porta, D. 2000. 'Social Capital, Beliefs in Government, and Political Corruption.' Pp. 202-230 in Disaffected Democracies: What's Troubling the Trilateral Countries?, edited by S. J. Pharr and R. D. Putnam. Princeton, NJ: Princeton University Press, https://doi.org/10.1515/9780691186849-013.

Poznyak, D., B. Meuleman, K. Abts and G. F. Bishop. 2014. 'Trust in American Government: Longitudinal Measurement Equivalence in the ANES, 1964-2008.' Social Indicators Research 118 (2): 741-758, https://doi.org/10.1007/s11205-013-0441-5.

R Core Team. 2020. 'R: A Language and Environment for Statistical Computing.' Retrieved 15 July 2020 (https://www.r-project.org/).

Robitzsch, A. 2019. 'Sirt: Supplementary Item Response Theory Models.' Retrieved 15 July 2020 (https://cran.r-project.org/package=sirt).

Rose-Ackerman, S. 2001. 'Trust and Honesty in Post-Socialist Societies.' Kyklos 54 (2-3):415-443, https:// doi.org/10.1111/1467-6435.00161.

Rothstein, B. and J. Teorell. 2008. 'What Is Quality of Government? A Theory of Impartial Government Institutions.' Governance 21 (2): 165-190, https://doi.org/10.1111/j.1468-0491.2008.00391.x.

Sacks, A., T. Tyler and M. Levi. 2009. 'Conceptualizing Legitimacy, Measuring Legitimating Beliefs.' American Behavioral Scientist 53: 354-375, https://doi.org/10.1177/0002764209338797.

Salmon, D. A., M. J. Sotir, W. K. Pan, J. L. Berg, S. B. Omer, S. Stokley, D. J. Hopfensperger, J. P. Davis and N. A. Halsey. 2009. 'Parental Vaccine Refusal in Wisconsin:

A Case-Control Study.' WMJ: Official Publication of the State Medical Society of Wisconsin 108 (1):17-23.

Schmidt-Catran, A. W. and M. Fairbrother. 2016. 'The Random Effects in Multilevel Models: Getting Them Wrong and Getting Them Right.' European Sociological Review 32 (1): 23-38, https://doi.org/10.1093/esr/jcv090.

Schoorman, F. D., R. C. Mayer and J. H. Davis. 2007. 'An Integrative Model of Organizational Trust: Past, Present, and Future.' Academy of Management Review 32 (2): 344-354, https://doi.org/10.5465/amr.2007.24348410.

Seligson, M. 2002. 'The Impact of Corruption on Regime Legitimacy: A Comparative Study of Four Latin American Countries.' The Journal of Politics 64 (2): 408-433, https://doi.org/10.1111/1468-2508.00132.

Sitkin, S. B. and N. L. Roth. 1993. 'Explaining the Limited Effectiveness of Legalistic 'Remedies' for Trust/Distrust.' Organization Science 4 (3): 367-392, https://doi.org/10.1287/orsc.4.3.367. https://doi.org/10.1287/orsc.4.3.367.

Standaert, S. 2015. 'Divining the Level of Corruption: A Bayesian State-Space Approach.' Journal of Comparative Economics 43 (3): 782-803, https://doi.org/10.1016/j.jce.2014.05.007.

Torcal, M. 2014. 'The Decline of Political Trust in Spain and Portugal.' American Behavioral Scientist 58 (12): 1542-1567, https://doi.org/10.1177/0002764214534662. 
Torcal, M. and J. R. Montero. 2006. Political Disaffection in Contemporary Democracies: Social Capital, Institutions and Politics. Oxon: Routledge, https://doi.org/10.4324/9780203086186.

Transparency International. 2020. Corruption Perceptions. Retrieved 15 June 2020 (https://www.transparency.org/files/content/pages/2019_CPI_Report_EN.pdf).

Tyler, T. R. 1990. Why People Obey the Law: Procedural Justice, Legitimacy, and Compliance. New Haven, CT: Yale University Press.

Tyler, T. R. 1998. 'Trust and Democratic Governance.' Pp. 269-294 in Trust and Governance, edited by V. Braithwaite and M. Levi. New York: Russell Sage Foundation.

Welzel, Christian. 2013. Freedom Rising: Human Empowerment and the Quest for Emancipation. New York: Cambridge University Press, https://doi.org/10.1017/CBO9781139540919.

Wickham, H., M. Averick, J. Bryan, W. Chang, L. McGowan, R. François, G. Grolemund, A. Hayes, L. Henry, J. Hester, M. Kuhn, T. Pedersen, E. Miller, S. Bache, K. Müller, J. Ooms, D. Robinson, D. Seidel, V. Spinu, K. Takahashi, D. Vaughan, C. Wilke, K. Woo and H. Yutani. 2019. 'Welcome to the Tidyverse.' Journal of Open Source Software 4 (43): 1686, https://doi.org/10.21105/joss.01686.

World Development Indicators. 2020a. 'GDP per Capita, PPP (Constant 2011 International \$).' Retrieved 10 July 2020 (http://data.worldbank.org/indicator/NY.GDP.PCAP.PP.KD).

World Development Indicators. 2020b. 'Unemployment, Total (\% of Total Labor Force).' Retrieved 10 July 2020 (https:// data.worldbank.org/indicator/SL.UEM.TOTL.ZS).

World Values Survey. 2012. Wave 6 (2010-2014) World Values Survey Official Questionnaire. http://www.worldvaluessurvey.org.

Wroe, A. 2014. 'Political Trust and Job Insecurity in 18 European Polities.' Journal of Trust Research 4 (2): 90-112, https:// doi.org/10.1080/21515581.2014.957291.

Wu, C. and R. Wilkes. 2018. 'Finding Critical Trusters: A Response Pattern Model of Political Trust.' International Journal of Comparative Sociology 59 (2): 110-138, https://doi.org/10.1177/0020715218761520.

You, J.-S. 2018. 'Trust and Corruption.' Pp. 473-496 in The Oxford Handbook of Social and Political Trust. Vol. 1, edited by E. M. Uslaner. Oxford: Oxford University Press, https://doi.org/10.1093/oxfordhb/9780190274801.013.22.

Závecz, G. 2017. 'Post-Communist Societies of Central and Eastern Europe.' Pp. 440-460 in Handbook on Political Trust, edited by S. Zmerli and T. W. G. van der Meer. Cheltenham: Edward Elgar Publishing, https://doi.org/10.4337/9781782545118.00038.

Zmerli, S. and J. C. Castillo. 2015. 'Income Inequality, Distributive Fairness and Political Trust in Latin America.' Social Science Research 52: 179-192, https:// doi.org/10.1016/j.ssresearch.2015.02.003. 


\section{Appendix}

Table A1. Country and year coverage-first part

\begin{tabular}{|c|c|c|c|c|c|c|c|c|}
\hline Country & WVS2 & EVS2 & WVS3 & EVS3 & WVS5 & EVS4 & WVS6 & EVS5 \\
\hline Albania & & & & & & 2008 & & 2018 \\
\hline Armenia & & & & & & 2008 & 2011 & 2018 \\
\hline Austria & & 1990 & & 1999 & & 2008 & & 2018 \\
\hline Azerbaijan & & & & & & & 2011 & 2018 \\
\hline Belarus & 1990 & & & 2000 & & 2008 & 2011 & 2018 \\
\hline Belgium & & 1990 & & 1999 & & 2009 & & \\
\hline $\begin{array}{l}\text { Bosnia \& } \\
\text { Herzegovina }\end{array}$ & & & & & & 2008 & & 2019 \\
\hline Bulgaria & & 1991 & & 1999 & 2006 & 2008 & & 2017 \\
\hline Croatia & & & & 1999 & & 2008 & & 2017 \\
\hline Czech Rep. & 1991 & 1991 & & 1999 & & 2008 & & 2017 \\
\hline Denmark & & 1990 & & 1999 & & 2008 & & 2017 \\
\hline Estonia & & & & 1999 & & 2008 & 2011 & 2018 \\
\hline Finland & & 1990 & 1996 & 2000 & 2005 & 2009 & & 2017 \\
\hline France & & 1990 & & 1999 & 2006 & 2008 & & 2018 \\
\hline Georgia & & & & & 2009 & 2008 & 2014 & 2018 \\
\hline Germany & & 1990 & & 1999 & 2006 & 2008 & 2013 & 2017 \\
\hline Greece & & & & 1999 & & 2008 & & \\
\hline Hungary & & 1991 & & 1999 & 2009 & 2008 & & 2018 \\
\hline Iceland & & 1990 & & 1999 & & 2009 & & 2017 \\
\hline Ireland & & 1990 & & 1999 & & 2008 & & \\
\hline Italy & & 1990 & & 1999 & 2005 & 2009 & & 2018 \\
\hline Latvia & & & & 1999 & & 2008 & & \\
\hline Lithuania & & & & 1999 & & 2008 & & 2018 \\
\hline Luxembourg & & & & 1999 & & 2008 & & \\
\hline Macedonia & & & & & & 2008 & & 2019 \\
\hline Malta & & 1991 & & 1999 & & 2008 & & \\
\hline Moldova & & & & & 2006 & 2008 & & \\
\hline Montenegro & & & & & & 2008 & & 2019 \\
\hline Netherlands & & 1990 & & 1999 & 2006 & 2008 & 2012 & 2017 \\
\hline
\end{tabular}


Table A1. Country and year coverage-second part

\begin{tabular}{lcccccccc}
\hline Country & WVS2 & EVS2 & WVS3 & EVS3 & WVS5 & EVS4 & WVS6 & EVS5 \\
\hline Norway & & 1990 & 1996 & & 2007 & 2008 & & 2018 \\
Poland & & 1990 & & 1999 & 2005 & 2008 & 2012 & 2017 \\
Portugal & & 1990 & & 1999 & & 2008 & & \\
Romania & & 1993 & & 1999 & 2005 & 2008 & 2012 & 2018 \\
Russia & 1990 & & & 1999 & 2006 & 2008 & 2011 & 2017 \\
Serbia & & & & & 2006 & 2008 & & 2018 \\
Slovakia & & & & 1999 & & 2008 & & 2017 \\
Slovenia & & 1992 & & 1999 & 2005 & 2008 & 2011 & 2017 \\
Spain & 1990 & 1990 & 1995 & 1999 & 2007 & 2008 & 2011 & 2017 \\
Sweden & & & 1996 & 1999 & 2006 & 2009 & 2011 & 2017 \\
Switzerland & & & 1996 & & 2007 & 2008 & & 2017 \\
Ukraine & & & 1999 & 2006 & 2008 & 2011 & \\
United Kingdom & 1990 & & 1999 & 2005 & 2009 & & 2018 \\
\hline
\end{tabular}




\section{Table A2. Summary statistics}

\begin{tabular}{lcccc}
\hline Variable name & Mean & $\begin{array}{c}\text { Standard } \\
\text { deviation }\end{array}$ & Minimum & Maximum \\
\hline $\begin{array}{l}\text { Individual-level variables } \\
\text { (N = 183 391) }\end{array}$ & & & & \\
Trust in institutions & 4.471 & 2.235 & 0 & 10 \\
Age & 46.8 & 17.078 & 18 & 108 \\
Female & 0.531 & & 0 & 1 \\
Education, years & 13.069 & 4.083 & 0 & 20 \\
Income scale & 0.03 & 0.998 & -3.093 & 5.735 \\
& & & & \\
Country-year-level variables & & & & \\
(N = 169) & 3.189 & 1.686 & 0.675 & 11.192 \\
$\begin{array}{l}\text { GDP per capita, 10 000 USD } \\
\begin{array}{l}\text { Public sector corruption } \\
\text { (V-Dem) }\end{array}\end{array}$ & 0.244 & 0.277 & 0.005 & 0.952 \\
$\begin{array}{l}\text { Bayesian Corruption } \\
\text { Indicator (QOG) }\end{array}$ & 0.357 & 0.165 & 0.078 & 0.662 \\
$\begin{array}{l}\text { Electoral democracy (V-Dem) } \\
\text { Unemployment }\end{array}$ & 0.755 & 0.192 & 0.205 & 0.924 \\
\hline
\end{tabular}

Source: Data from the European Values Study waves 2-5, World Values Survey waves 2, 3, 5, 6, World Bank, Varieties of Democracy, Quality of Government. 
Table A3. Political trust: variance decomposition

\begin{tabular}{lc}
\hline Political trust & Empty model \\
\hline Constant & $4423^{* * *}$ \\
& $(0.114)$ \\
Fit statistics & \\
Log Likelihood & -404498.9 \\
Akaike Inf. Crit. & 809005.8 \\
Bayesian Inf. Crit. & 809046.3 \\
& \\
Variance components & \\
Country & 0.483 \\
Survey & 0.220 \\
Individual & 4.333 \\
N individuals & 183391 \\
N surveys & 169 \\
N countries & 42 \\
\hline
\end{tabular}




\section{Table A4. Political trust: approximate invariance test}

Items: trust in parliament, trust in justice system, trust in civil service.

N surveys: 169

$N$ individuals: 183391

Multi-Group Factor Analysis Alignment with the sirt package [Robitzsch 2019]:

Alignment Power Values $=0.250 .25$

Alignment Scale Values $=11$

Epsilon Value $=0.001$

Alignment Results Lambda Parameters

Parameter tolerance value $=1$

Total number of items $=507$

Number of unique item parameters $=3$

Percentage of non-invariant item parameters $=0 \%$

Joint item parameters

Trust in parliament: 0.575

Trust in civil service: 0.544

Trust in justice system: 0.463

Alignment Results Nu Parameters

Joint item parameters

Trust in parliament: 2.175

Trust in civil service: 2.327

Trust in justice system: 2.395 
Table A5. Conditional models 1.1-1.5: Total effects-first part

\begin{tabular}{|c|c|c|c|c|c|}
\hline & Model 1.1 & Model 1.2 & Model 1.3 & Model 1.4 & Model 1.5 \\
\hline Political trust & GDP pc & $\begin{array}{l}\text { Corruption } \\
\text { (V-Dem) }\end{array}$ & $\begin{array}{c}\text { Corruption } \\
\text { (QOG) }\end{array}$ & Democracy & $\begin{array}{l}\text { Unemploy- } \\
\text { ment }\end{array}$ \\
\hline $\begin{array}{l}\text { GDP per capita } \\
\text { (10 000 USD) }\end{array}$ & $\begin{array}{l}0.276^{* * *} \\
(0.07)\end{array}$ & & & & \\
\hline Unemployment & & $\begin{array}{l}-3.122^{* * *} \\
(1.183)\end{array}$ & & & \\
\hline $\begin{array}{l}\text { Public sector } \\
\text { corruption (V-Dem) }\end{array}$ & & & $\begin{array}{l}-0.757^{*} \\
(0.42)\end{array}$ & & \\
\hline $\begin{array}{l}\text { Bayesian Corruption } \\
\text { Indicator (QOG) }\end{array}$ & & & & $\begin{array}{l}-3.684^{* * *} \\
(0.668)\end{array}$ & \\
\hline Democracy & & & & & $\begin{array}{l}-2.291^{* * *} \\
(0.524)\end{array}$ \\
\hline 'New' EU & $\begin{array}{l}-0.753^{* * *} \\
(0.237)\end{array}$ & $\begin{array}{l}-0.580^{* *} \\
(0.241)\end{array}$ & $\begin{array}{l}-0.670^{* *} \\
(0.274)\end{array}$ & $\begin{array}{l}-0.651^{* * *} \\
(0.200)\end{array}$ & $\begin{array}{c}0.297 \\
(0.298)\end{array}$ \\
\hline ‘Old' EU & $\begin{array}{l}-1.057^{* * *} \\
(0.327)\end{array}$ & $\begin{array}{l}-0.232 \\
(0.227)\end{array}$ & $\begin{array}{l}-0.464 \\
(0.317)\end{array}$ & $\begin{array}{l}-1.105^{* * *} \\
(0.266)\end{array}$ & $\begin{array}{l}0.908^{* * *} \\
(0.314)\end{array}$ \\
\hline Control variables & & & & & \\
\hline Age & $\begin{array}{l}-0.272^{* * *} \\
(0.016)\end{array}$ & $\begin{array}{l}-0.259^{* * *} \\
(0.016)\end{array}$ & $\begin{array}{l}-0.272^{* * *} \\
(0.016)\end{array}$ & $\begin{array}{l}-0.275^{* * *} \\
(0.016)\end{array}$ & $\begin{array}{l}-0.259^{* * *} \\
(0.016)\end{array}$ \\
\hline Age squared & $\begin{array}{l}0.036^{* * *} \\
(0.002)\end{array}$ & $\begin{array}{l}0.035^{* * *} \\
(0.002)\end{array}$ & $\begin{array}{l}0.036^{* * *} \\
(0.002)\end{array}$ & $\begin{array}{l}0.037^{* * *} \\
(0.002)\end{array}$ & $\begin{array}{l}0.035^{* * *} \\
(0.002)\end{array}$ \\
\hline Sex (1 = female $)$ & $\begin{array}{l}0.113^{* * *} \\
(0.010)\end{array}$ & $\begin{array}{l}0.113^{* * *} \\
(0.010)\end{array}$ & $\begin{array}{l}0.113^{* * *} \\
(0.010)\end{array}$ & $\begin{array}{l}0.112^{* * *} \\
(0.010)\end{array}$ & $\begin{array}{l}0.113^{* * *} \\
(0.010)\end{array}$ \\
\hline Education, years & $\begin{array}{l}-0.039^{* * * *} \\
(0.003)\end{array}$ & $\begin{array}{l}-0.039^{* * *} \\
(0.003)\end{array}$ & $\begin{array}{l}-0.039^{* * *} \\
(0.003)\end{array}$ & $\begin{array}{l}-0.035^{* * *} \\
(0.003)\end{array}$ & $\begin{array}{l}-0.039^{* * *} \\
(0.003)\end{array}$ \\
\hline $\begin{array}{l}\text { 'New' EU * } \\
\text { Education, years }\end{array}$ & $\begin{array}{l}0.028^{* * *} \\
(0.004)\end{array}$ & $\begin{array}{l}0.029^{* * *} \\
(0.004)\end{array}$ & $\begin{array}{l}0.028^{* * *} \\
(0.004)\end{array}$ & $\begin{array}{l}0.025^{* * *} \\
(0.004)\end{array}$ & $\begin{array}{l}0.029^{* * * *} \\
(0.004)\end{array}$ \\
\hline $\begin{array}{l}\text { 'Old' EU * } \\
\text { Education, years }\end{array}$ & $\begin{array}{l}0.072^{* * *} \\
(0.003)\end{array}$ & $\begin{array}{l}0.071^{* * *} \\
(0.003)\end{array}$ & $\begin{array}{l}0.072^{* * * *} \\
(0.003)\end{array}$ & $\begin{array}{l}0.068^{* * *} \\
(0.003)\end{array}$ & $\begin{array}{l}0.071^{* * *} \\
(0.003)\end{array}$ \\
\hline Income scale & $\begin{array}{l}0.113^{* * *} \\
(0.005)\end{array}$ & $\begin{array}{l}0.117^{* * *} \\
(0.005)\end{array}$ & $\begin{array}{l}0.113^{* * *} \\
(0.005)\end{array}$ & $\begin{array}{l}0.121^{* * *} \\
(0.005)\end{array}$ & $\begin{array}{l}0.117^{* * *} \\
(0.005)\end{array}$ \\
\hline
\end{tabular}


Table A5. Conditional models 1.1-1.5: Total effects-second part

\begin{tabular}{|c|c|c|c|c|c|}
\hline & Model 1.1 & Model 1.2 & Model 1.3 & Model 1.4 & Model 1.5 \\
\hline Political trust & GDP pc & $\begin{array}{l}\text { Corruption } \\
\text { (V-Dem) }\end{array}$ & $\begin{array}{c}\text { Corruption } \\
\text { (QOG) }\end{array}$ & Democracy & $\begin{array}{c}\text { Unemploy- } \\
\text { ment }\end{array}$ \\
\hline \multirow[t]{2}{*}{ Year } & $-0.017^{* * *}$ & -0.003 & -0.001 & -0.001 & 0.0003 \\
\hline & $(0.006)$ & $(0.005)$ & $(0.005)$ & $(0.005)$ & $(0.004)$ \\
\hline \multirow[t]{2}{*}{ Constant } & $4.851^{* * *}$ & $5.314^{* * *}$ & $5.355^{* * *}$ & $6.812^{* * *}$ & $5.918^{* * *}$ \\
\hline & $(0.187)$ & $(0.263)$ & $(0.334)$ & $(0.400)$ & $(0.317)$ \\
\hline \multicolumn{6}{|c|}{ Variance components } \\
\hline Country & 0.205 & 0.230 & 0.140 & 0.292 & 0.241 \\
\hline Survey & 0.214 & 0.227 & 0.201 & 0.188 & 0.215 \\
\hline Individual & 4.285 & 4.285 & 4.242 & 4.274 & 4.274 \\
\hline \multicolumn{6}{|l|}{ Fit statistics } \\
\hline Log Likelihood & -403507.9 & -393809.6 & -403511.9 & -382944.1 & -393804.8 \\
\hline Akaike Inf. Crit. & 807045.7 & 787649.1 & 807053.7 & 765918.2 & 787639.5 \\
\hline Bayesian Inf. Crit. & 807197.5 & 787800.9 & 807205.5 & 766069.2 & 787791.3 \\
\hline $\mathrm{N}$ individuals & 183391 & 183391 & 183391 & 174324 & 183391 \\
\hline N surveys & 169 & 169 & 169 & 161 & 169 \\
\hline $\mathrm{N}$ countries & 42 & 42 & 42 & 42 & 42 \\
\hline
\end{tabular}

Note: Standard errors in parentheses. $+\mathrm{p}<0.1,{ }^{*} \mathrm{p}<0.05,{ }^{* *} \mathrm{p}<0.01,{ }^{* * *} \mathrm{p}<0.001$.

Data source: European Values Study waves 2-5, World Values Survey waves 2, 3, 5, 6, World Bank, Varieties of Democracy, Quality of Government. 
Table A6. Conditional models 2.1-2.5: Total effects and region interactions—first part

\begin{tabular}{|c|c|c|c|c|c|}
\hline & Model 2.1 & Model 2.2 & Model 2.3 & Model 2.4 & Model 2.5 \\
\hline Political trust & GDP pc & $\begin{array}{l}\text { Corruption } \\
\text { (V-Dem) }\end{array}$ & $\begin{array}{c}\text { Corruption } \\
\text { (QOG) }\end{array}$ & Democracy & $\begin{array}{l}\text { Unemploy- } \\
\text { ment }\end{array}$ \\
\hline GDP per capita (10 000 USD) & $\begin{array}{l}0.756^{* * *} \\
(0.234)\end{array}$ & & & & \\
\hline Unemployment & & $\begin{array}{l}-1.957 \\
(1.783)\end{array}$ & & & \\
\hline $\begin{array}{l}\text { Public sector corruption } \\
\text { (V-Dem) }\end{array}$ & & & $\begin{array}{l}-0.288 \\
(0.573)\end{array}$ & & \\
\hline $\begin{array}{l}\text { Bayesian Corruption Indica- } \\
\text { tor (QOG) }\end{array}$ & & & & $\begin{array}{l}-2.983^{*} \\
(1.565)\end{array}$ & \\
\hline Democracy & & & & & $\begin{array}{l}-2.752^{* * *} \\
(0.776)\end{array}$ \\
\hline 'New' EU & $\begin{array}{c}0.372 \\
(0.451)\end{array}$ & $\begin{array}{l}-0.565 \\
(0.378)\end{array}$ & $\begin{array}{l}-0.422 \\
(0.445)\end{array}$ & $\begin{array}{l}-0.215 \\
(1.053)\end{array}$ & $\begin{array}{l}-0.187 \\
(0.727)\end{array}$ \\
\hline ‘Old’ EU & $\begin{array}{r}-0.493 \\
(0.476)\end{array}$ & $\begin{array}{c}0.114 \\
(0.344)\end{array}$ & $\begin{array}{c}0.060 \\
(0.415)\end{array}$ & $\begin{array}{l}-0.709 \\
(0.853)\end{array}$ & $\begin{array}{l}-0.851 \\
(2.571)\end{array}$ \\
\hline $\begin{array}{l}\text { ‘New' EU: GDP per capita } \\
\text { (10 } 000 \text { USD) }\end{array}$ & $\begin{array}{l}-0.674^{* * *} \\
(0.241)\end{array}$ & & & & \\
\hline $\begin{array}{l}\text { ‘Old’ EU: GDP per capita } \\
\text { (10 000 USD) }\end{array}$ & $\begin{array}{l}-0.457^{* *} \\
(0.230)\end{array}$ & & & & \\
\hline 'New' EU: Unemployment & & $\begin{array}{c}0.446 \\
(2.937)\end{array}$ & & & \\
\hline 'Old' EU: Unemployment & & $\begin{array}{l}-3.872 \\
(2.680)\end{array}$ & & & \\
\hline $\begin{array}{l}\text { ‘New' EU: Public sector cor- } \\
\text { ruption (V-Dem) }\end{array}$ & & & $\begin{array}{r}-0.326 \\
(0.831)\end{array}$ & & \\
\hline $\begin{array}{l}\text { 'Old' EU: Public sector cor- } \\
\text { ruption (V-Dem) }\end{array}$ & & & $\begin{array}{l}-4.067^{* * *} \\
(1.426)\end{array}$ & & \\
\hline $\begin{array}{l}\text { ‘New’ EU: Bayesian } \\
\text { Corruption Indicator (QOG) }\end{array}$ & & & & $\begin{array}{l}-0.859 \\
(2.084)\end{array}$ & \\
\hline $\begin{array}{l}\text { ‘Old’ EU: Bayesian } \\
\text { Corruption Indicator (QOG) }\end{array}$ & & & & $\begin{array}{l}-0.850 \\
(1.792)\end{array}$ & \\
\hline
\end{tabular}


Table A6. Conditional models 2.1-2.5: Total effects and region interactions-second part

\begin{tabular}{|c|c|c|c|c|c|}
\hline \multirow[b]{2}{*}{ Political trust } & Model 2.1 & Model 2.2 & Model 2.3 & Model 2.4 & Model 2.5 \\
\hline & GDP pc & $\begin{array}{l}\text { Corruption } \\
\text { (V-Dem) }\end{array}$ & $\begin{array}{l}\text { Corruption } \\
\text { (QOG) }\end{array}$ & Democracy & $\begin{array}{c}\text { Unemploy- } \\
\text { ment }\end{array}$ \\
\hline \multirow[t]{2}{*}{ ‘New' EU: Democracy } & & & & & 0.803 \\
\hline & & & & & $(1.075)$ \\
\hline \multirow[t]{2}{*}{ ‘Old’ EU: Democracy } & & & & & 2.218 \\
\hline & & & & & $(2.990)$ \\
\hline \multicolumn{6}{|l|}{ Control variables } \\
\hline \multirow[t]{2}{*}{ Age } & $-0.272^{* * *}$ & $-0.259^{* * *}$ & $-0.272^{* * *}$ & $-0.275^{* * *}$ & $-0.259^{* * *}$ \\
\hline & $(0.016)$ & $(0.016)$ & $(0.016)$ & $(0.016)$ & $(0.016)$ \\
\hline \multirow[t]{2}{*}{ Age squared } & $0.036^{* * *}$ & $0.035^{* * * *}$ & $0.036^{* * *}$ & $0.037^{* * * *}$ & $0.035^{* * *}$ \\
\hline & $(0.002)$ & $(0.002)$ & $(0.002)$ & $(0.002)$ & $(0.002)$ \\
\hline \multirow[t]{2}{*}{ Sex (1 = female $)$} & $0.113^{* * *}$ & $0.113^{* * *}$ & $0.113^{* * *}$ & $0.112^{* * *}$ & $0.113^{* * *}$ \\
\hline & $(0.010)$ & $(0.010)$ & $(0.010)$ & $(0.010)$ & $(0.010)$ \\
\hline \multirow[t]{2}{*}{ Education, years } & $-0.039^{* * *}$ & $-0.039^{* * * *}$ & $-0.039^{* * *}$ & $-0.035^{* * *}$ & $-0.039^{* * *}$ \\
\hline & $(0.003)$ & $(0.003)$ & $(0.003)$ & $(0.003)$ & $(0.003)$ \\
\hline \multirow{2}{*}{$\begin{array}{l}\text { ‘New' EU * Education, } \\
\text { years }\end{array}$} & $0.028^{* * *}$ & $0.029^{* * *}$ & $0.028^{* * *}$ & $0.025^{* * *}$ & $0.029^{* * *}$ \\
\hline & $(0.004)$ & $(0.004)$ & $(0.004)$ & $(0.004)$ & $(0.004)$ \\
\hline \multirow{2}{*}{$\begin{array}{l}\text { ‘Old’ EU * Education, } \\
\text { years }\end{array}$} & $0.072^{* * *}$ & $0.071^{* * *}$ & $0.072^{* * *}$ & $0.068^{* * *}$ & $0.071^{* * *}$ \\
\hline & $(0.003)$ & $(0.003)$ & $(0.003)$ & $(0.003)$ & $(0.003)$ \\
\hline \multirow[t]{2}{*}{ Income scale } & $0.113^{* * *}$ & $0.117^{* * *}$ & $0.113^{* * *}$ & $0.121^{* * *}$ & $0.117^{* * *}$ \\
\hline & $(0.005)$ & $(0.005)$ & $(0.005)$ & $(0.005)$ & $(0.005)$ \\
\hline \multirow[t]{2}{*}{ Year } & $-0.016^{* *}$ & -0.003 & -0.002 & -0.001 & -0.0001 \\
\hline & $(0.006)$ & $(0.005)$ & $(0.005)$ & $(0.005)$ & $(0.004)$ \\
\hline \multirow[t]{2}{*}{ Constant } & $4.163^{* * *}$ & $5.162^{* * *}$ & $5.075^{* * *}$ & $6.450^{* * *}$ & $6.142^{* * *}$ \\
\hline & $(0.348)$ & $(0.306)$ & $(0.402)$ & $(0.836)$ & $(0.418)$ \\
\hline \multicolumn{6}{|l|}{ Variance components } \\
\hline Country & 0.223 & 0.236 & 0.190 & 0.149 & 0.274 \\
\hline Survey & 0.200 & 0.214 & 0.227 & 0.202 & 0.193 \\
\hline Individual & 4.285 & 4.274 & 4.285 & 4.242 & 4.274 \\
\hline
\end{tabular}


Table A6. Conditional models 2.1-2.5: Total effects and region interactions-third part

\begin{tabular}{lrrrrrr}
\hline & Model 2.1 & Model 2.2 & Model 2.3 & Model 2.4 & Model 2.5 \\
\cline { 2 - 6 } Political trust & GDP pc & $\begin{array}{c}\text { Corruption } \\
\text { (V-Dem) }\end{array}$ & $\begin{array}{c}\text { Corruption } \\
\text { (QOG) }\end{array}$ & $\begin{array}{c}\text { Democracy } \\
\text { Fit statistics }\end{array}$ & $\begin{array}{c}\text { Unemploy- } \\
\text { ment }\end{array}$ \\
Log Likelihood & -403505.4 & -393804.4 & -403505.9 & -382941.1 & -393801.4 \\
Akaike Inf. Crit. & 807044.8 & 787642.7 & 807045.9 & 765916.2 & 787636.7 \\
Bayesian Inf. Crit. & 807216.8 & 787814.7 & 807217.9 & 766087.4 & 787808.7 \\
N individuals & 183391 & 183391 & 183391 & 174324 & 183391 \\
N surveys & 169 & 169 & 169 & 161 & 169 \\
N countries & 42 & 42 & 42 & 42 & 42 \\
\hline
\end{tabular}

Note: Standard errors in parentheses. $+\mathrm{p}<0.1,{ }^{*} \mathrm{p}<0.05,{ }^{* *} \mathrm{p}<0.01,{ }^{* * *} \mathrm{p}<0.001$. Data source: European Values Study waves 2-5, World Values Survey waves 2, 3, 5, 6, World Bank, Varieties of Democracy, Quality of Government. 
Table A7. Conditional models 3.1-3.5: between- and within-country effects-first part

\begin{tabular}{|c|c|c|c|c|c|}
\hline \multirow[b]{2}{*}{ Political trust } & Model 3.1 & Model 3.2 & Model 3.3 & Model 3.4 & Model 3.5 \\
\hline & GDP pc & $\begin{array}{l}\text { Corruption } \\
\text { (V-Dem) }\end{array}$ & $\begin{array}{l}\text { Corruption } \\
\text { (QOG) }\end{array}$ & Democracy & $\begin{array}{l}\text { Unemploy- } \\
\text { ment }\end{array}$ \\
\hline \multirow{2}{*}{$\begin{array}{l}\text { GDP per capita: } \\
\text { time-invariant }\end{array}$} & $0.252^{* * *}$ & & & & \\
\hline & $(0.080)$ & & & & \\
\hline \multirow{2}{*}{$\begin{array}{l}\text { GDP per capita: } \\
\text { time-varying }\end{array}$} & $0.346^{* * *}$ & & & & \\
\hline & $(0.134)$ & & & & \\
\hline \multirow{2}{*}{$\begin{array}{l}\text { Unemployment: } \\
\text { time-invariant }\end{array}$} & & $-4.557^{* *}$ & & & \\
\hline & & (2.033) & & & \\
\hline \multirow{2}{*}{$\begin{array}{l}\text { Unemployment: } \\
\text { time-varying }\end{array}$} & & $-2.427^{*}$ & & & \\
\hline & & (1.456) & & & \\
\hline \multirow{2}{*}{$\begin{array}{l}\text { Public sector corruption: } \\
\text { time-invariant }\end{array}$} & & & $-1.268^{* *}$ & & \\
\hline & & & $(0.510)$ & & \\
\hline \multirow{2}{*}{$\begin{array}{l}\text { Public sector corruption: } \\
\text { time-varying }\end{array}$} & & & 0.340 & & \\
\hline & & & $(0.774)$ & & \\
\hline \multirow{2}{*}{$\begin{array}{l}\text { Bayesian Corruption } \\
\text { Indicator: time-invariant }\end{array}$} & & & & $-3.960^{* * *}$ & \\
\hline & & & & $(0.748)$ & \\
\hline \multirow{2}{*}{$\begin{array}{l}\text { Bayesian Corruption } \\
\text { Indicator: time-varying }\end{array}$} & & & & -2.490 & \\
\hline & & & & (1.590) & \\
\hline \multirow{2}{*}{$\begin{array}{l}\text { Democracy: } \\
\text { time-invariant }\end{array}$} & & & & & -0.841 \\
\hline & & & & & (1.180) \\
\hline \multirow{2}{*}{$\begin{array}{l}\text { Democracy: } \\
\text { time-varying }\end{array}$} & & & & & $-2.746^{* * *}$ \\
\hline & & & & & $(0.591)$ \\
\hline \multirow[t]{2}{*}{ ‘New’ EU } & $-0.752^{* * *}$ & $-0.622^{* *}$ & $-0.851^{* * *}$ & $-0.664^{* * *}$ & -0.134 \\
\hline & $(0.238)$ & $(0.249)$ & $(0.290)$ & $(0.201)$ & $(0.441)$ \\
\hline \multirow[t]{2}{*}{ ‘Old’ EU } & $-0.994^{* * *}$ & -0.327 & $-0.766^{* *}$ & $-1.183^{* * *}$ & 0.293 \\
\hline & $(0.344)$ & $(0.247)$ & $(0.358)$ & $(0.282)$ & $(0.541)$ \\
\hline \multicolumn{6}{|l|}{ Control variables } \\
\hline \multirow[t]{2}{*}{ Age } & $-0.272^{* * *}$ & $-0.272^{* * *}$ & $-0.272^{* * *}$ & $-0.275^{* * *}$ & $-0.272^{* * *}$ \\
\hline & $(0.016)$ & $(0.016)$ & $(0.016)$ & $(0.016)$ & (0.016) \\
\hline \multirow[t]{2}{*}{ Age squared } & $0.036^{* * *}$ & $0.036^{* * *}$ & $0.036^{* * *}$ & $0.037^{* * *}$ & $0.036^{* * *}$ \\
\hline & $(0.002)$ & $(0.002)$ & $(0.002)$ & $(0.002)$ & $(0.002)$ \\
\hline
\end{tabular}


Table A7. Conditional models 3.1-3.5: between- and within-country effects-second part

\begin{tabular}{|c|c|c|c|c|c|}
\hline \multirow[b]{2}{*}{ Political trust } & Model 3.1 & Model 3.2 & Model 3.3 & Model 3.4 & Model 3.5 \\
\hline & GDP pc & $\begin{array}{c}\text { Corruption } \\
\text { (V-Dem) }\end{array}$ & $\begin{array}{l}\text { Corruption } \\
\text { (QOG) }\end{array}$ & Democracy & $\begin{array}{l}\text { Unemploy- } \\
\text { ment }\end{array}$ \\
\hline \multirow[t]{2}{*}{ Sex $(1=$ female $)$} & $0.113^{* * *}$ & $0.113^{* * *}$ & $0.113^{* * *}$ & $0.112^{* * *}$ & $0.113^{* * *}$ \\
\hline & $(0.010)$ & $(0.010)$ & $(0.010)$ & $(0.010)$ & $(0.010)$ \\
\hline \multirow[t]{2}{*}{ Education, years } & $-0.039^{* * *}$ & $-0.039^{* * *}$ & $-0.039^{* * *}$ & $-0.035^{* * *}$ & $-0.039^{* * *}$ \\
\hline & $(0.003)$ & $(0.003)$ & $(0.003)$ & $(0.003)$ & $(0.003)$ \\
\hline \multirow{2}{*}{$\begin{array}{l}\text { ‘New' EU * Education, } \\
\text { years }\end{array}$} & $0.028^{* * *}$ & $0.028^{* * *}$ & $0.028^{* * *}$ & $0.025^{* * *}$ & $0.028^{* * *}$ \\
\hline & $(0.004)$ & $(0.004)$ & $(0.004)$ & $(0.004)$ & $(0.004)$ \\
\hline \multirow{2}{*}{$\begin{array}{l}\text { 'Old' EU * Education, } \\
\text { years }\end{array}$} & $0.072^{* * *}$ & $0.072^{* * *}$ & $0.072^{* * *}$ & $0.068^{* * *}$ & $0.072^{* * *}$ \\
\hline & $(0.003)$ & $(0.003)$ & $(0.003)$ & $(0.003)$ & $(0.003)$ \\
\hline \multirow[t]{2}{*}{ Income scale } & $0.113^{* * *}$ & $0.113^{* * *}$ & $0.113^{* * *}$ & $0.121^{* * *}$ & $0.113^{* * *}$ \\
\hline & $(0.005)$ & $(0.005)$ & $(0.005)$ & $(0.005)$ & $(0.005)$ \\
\hline \multirow[t]{2}{*}{ Year } & $-0.022^{* *}$ & -0.002 & 0.0003 & 0.0003 & -0.0001 \\
\hline & $(0.009)$ & $(0.005)$ & $(0.005)$ & $(0.005)$ & $(0.004)$ \\
\hline \multirow[t]{2}{*}{ Constant } & $4.960^{* * *}$ & $5.509^{* * *}$ & $5.671^{* * *}$ & $6.940^{* * *}$ & $5.271^{* * *}$ \\
\hline & $(0.259)$ & $(0.333)$ & $(0.377)$ & $(0.430)$ & $(0.577)$ \\
\hline \multicolumn{6}{|l|}{ Variance components } \\
\hline Country & 0.207 & 0.232 & 0.220 & 0.141 & 0.270 \\
\hline Survey & 0.214 & 0.221 & 0.226 & 0.202 & 0.192 \\
\hline Individual & 4.285 & 4.285 & 4.285 & 4.242 & 4.285 \\
\hline \multicolumn{6}{|l|}{ Fit statistics } \\
\hline Log Likelihood & -403508.6 & -403506.8 & -403509.6 & -382942.3 & -403501.5 \\
\hline Akaike Inf. Crit. & 807049.2 & 807045.5 & 807051.2 & 765916.5 & 807035.1 \\
\hline Bayesian Inf. Crit. & 807211.2 & 807207.4 & 807213.1 & 766077.6 & 807197.0 \\
\hline $\mathrm{N}$ individuals & 183391 & 183391 & 183391 & 174324 & 183391 \\
\hline N surveys & 169 & 169 & 169 & 161 & 169 \\
\hline $\mathrm{N}$ countries & 42 & 42 & 42 & 42 & 42 \\
\hline
\end{tabular}

Note: Standard errors in parentheses. $+\mathrm{p}<0.1{ }^{*} \mathrm{p}<0.05,{ }^{* *} \mathrm{p}<0.01,{ }^{* * *} \mathrm{p}<0.001$.

Data source: European Values Study waves 2-5, World Values Survey waves 2, 3, 5, 6, World Bank, Varieties of Democracy, Quality of Government. 
Table A8. Conditional models 4.1-4.5: between- and within-country effects and region interactions-first part

\begin{tabular}{|c|c|c|c|c|c|}
\hline \multirow[b]{2}{*}{ Political trust } & Model 4.1 & Model 4.2 & Model 4.3 & Model 4.4 & Model 4.5 \\
\hline & GDP pc & $\begin{array}{l}\text { Corruption } \\
\text { (V-Dem) }\end{array}$ & $\begin{array}{l}\text { Corruption } \\
\text { (QOG) }\end{array}$ & Democracy & $\begin{array}{l}\text { Unemploy- } \\
\text { ment }\end{array}$ \\
\hline \multirow{2}{*}{$\begin{array}{l}\text { GDP per capita: } \\
\text { time-invariant }\end{array}$} & 0.416 & & & & \\
\hline & $(0.394)$ & & & & \\
\hline \multirow{2}{*}{$\begin{array}{l}\text { GDP per capita: } \\
\text { time-varying }\end{array}$} & $1.054^{* * *}$ & & & & \\
\hline & $(0.301)$ & & & & \\
\hline \multirow{2}{*}{$\begin{array}{l}\text { Unemployment: } \\
\text { time-invariant }\end{array}$} & & -3.038 & & & \\
\hline & & $(2.586)$ & & & \\
\hline \multirow{2}{*}{$\begin{array}{l}\text { Unemployment: } \\
\text { time-varying }\end{array}$} & & -1.198 & & & \\
\hline & & $(2.477)$ & & & \\
\hline \multirow{2}{*}{$\begin{array}{l}\text { Public sector corruption: } \\
\text { time-invariant }\end{array}$} & & & 0.322 & & \\
\hline & & & $(0.741)$ & & \\
\hline \multirow{2}{*}{$\begin{array}{l}\text { Public sector corruption: } \\
\text { time-varying }\end{array}$} & & & -1.460 & & \\
\hline & & & (1.110) & & \\
\hline \multirow{2}{*}{$\begin{array}{l}\text { Bayesian Corruption } \\
\text { Indicator: time-invariant }\end{array}$} & & & & $-3.515^{*}$ & \\
\hline & & & & $(2.057)$ & \\
\hline \multirow{2}{*}{$\begin{array}{l}\text { Bayesian Corruption } \\
\text { Indicator: time-varying }\end{array}$} & & & & -1.985 & \\
\hline & & & & (2.808) & \\
\hline \multirow{2}{*}{$\begin{array}{l}\text { Democracy: } \\
\text { time-invariant }\end{array}$} & & & & & $-4.085^{* * *}$ \\
\hline & & & & & $(1.357)$ \\
\hline \multirow{2}{*}{$\begin{array}{l}\text { Democracy: } \\
\text { time-varying }\end{array}$} & & & & & $-2.270^{* *}$ \\
\hline & & & & & $(0.943)$ \\
\hline \multirow[t]{2}{*}{ ‘New’ EU } & -0.713 & -0.670 & 0.318 & -0.531 & $-4.860^{* * *}$ \\
\hline & $(0.923)$ & $(0.679)$ & $(0.556)$ & $(1.350)$ & $(1.420)$ \\
\hline \multirow[t]{2}{*}{ ‘Old’ EU } & -0.652 & 0.217 & 0.477 & -0.915 & -9.117 \\
\hline & $(0.664)$ & $(0.500)$ & $(0.520)$ & (1.108) & (5.643) \\
\hline \multirow{2}{*}{$\begin{array}{l}\text { ‘New' EU * GDP per capita: } \\
\text { time-invariant }\end{array}$} & -0.035 & & & & \\
\hline & $(0.523)$ & & & & \\
\hline \multirow{2}{*}{$\begin{array}{l}\text { ‘Old’ EU * GDP per capita: } \\
\text { time-invariant }\end{array}$} & -0.177 & & & & \\
\hline & $(0.404)$ & & & & \\
\hline \multirow{2}{*}{$\begin{array}{l}\text { ‘New' EU * GDP per capita: } \\
\text { time-varying }\end{array}$} & $-0.881^{* * *}$ & & & & \\
\hline & $(0.278)$ & & & & \\
\hline
\end{tabular}


Table A8. Conditional models 4.1-4.5: between- and within-country effects and region interactions-second part

\begin{tabular}{|c|c|c|c|c|c|}
\hline & Model 4.1 & Model 4.2 & Model 4.3 & Model 4.4 & Model 4.5 \\
\hline Political trust & GDP pc & $\begin{array}{c}\text { Corruption } \\
\text { (V-Dem) }\end{array}$ & $\begin{array}{c}\text { Corruption } \\
\text { (QOG) }\end{array}$ & Democracy & $\begin{array}{l}\text { Unemploy- } \\
\text { ment }\end{array}$ \\
\hline $\begin{array}{l}\text { ‘Old' EU * GDP per capita: } \\
\text { time-varying }\end{array}$ & $\begin{array}{l}-0.584^{* *} \\
(0.271)\end{array}$ & & & & \\
\hline $\begin{array}{l}\text { ‘New' EU * Unemployment: } \\
\text { time-invariant }\end{array}$ & & $\begin{array}{c}1.315 \\
(6.590)\end{array}$ & & & \\
\hline $\begin{array}{l}\text { ‘Old’ EU * Unemployment: } \\
\text { time-invariant }\end{array}$ & & $\begin{array}{l}-6.366 \\
(4.817)\end{array}$ & & & \\
\hline $\begin{array}{l}\text { 'New' EU * Unemployment: } \\
\text { time-varying }\end{array}$ & & $\begin{array}{c}0.022 \\
(3.481)\end{array}$ & & & \\
\hline $\begin{array}{l}\text { ‘Old' EU * Unemployment: } \\
\text { time-varying }\end{array}$ & & $\begin{array}{l}-3.388 \\
(3.383)\end{array}$ & & & \\
\hline $\begin{array}{l}\text { 'New' EU * Public sector } \\
\text { corruption: time-invariant }\end{array}$ & & & $\begin{array}{l}-1.966^{*} \\
(1.015)\end{array}$ & & \\
\hline $\begin{array}{l}\text { ‘Old' EU * Public sector } \\
\text { corruption: time-invariant }\end{array}$ & & & $\begin{array}{l}-4.589^{* * *} \\
(1.506)\end{array}$ & & \\
\hline $\begin{array}{l}\text { 'New' EU * Public sector } \\
\text { corruption: time-varying }\end{array}$ & & & $\begin{array}{l}3.217^{* *} \\
(1.519)\end{array}$ & & \\
\hline $\begin{array}{l}\text { ‘Old' EU * Public sector cor- } \\
\text { ruption: time-varying }\end{array}$ & & & $\begin{array}{l}-3.789 \\
(5.508)\end{array}$ & & \\
\hline $\begin{array}{l}\text { ‘New’ EU * Bayesian Corrup- } \\
\text { tion Indicator: time-invariant }\end{array}$ & & & & $\begin{array}{l}-0.245 \\
(2.664)\end{array}$ & \\
\hline $\begin{array}{l}\text { ‘Old' EU * Bayesian Corrup- } \\
\text { tion Indicator: time-invariant }\end{array}$ & & & & $\begin{array}{l}-0.612 \\
(2.267)\end{array}$ & \\
\hline $\begin{array}{l}\text { ‘New’ EU * Bayesian Corrup- } \\
\text { tion Indicator: time-varying }\end{array}$ & & & & $\begin{array}{l}-1.979 \\
(3.838)\end{array}$ & \\
\hline $\begin{array}{l}\text { ‘Old' EU * Bayesian Corrup- } \\
\text { tion Indicator: time-varying }\end{array}$ & & & & $\begin{array}{c}0.371 \\
(3.785)\end{array}$ & \\
\hline $\begin{array}{l}\text { ‘New' EU * Democracy: } \\
\text { time-invariant }\end{array}$ & & & & & $\begin{array}{l}7.444^{* * *} \\
(2.122)\end{array}$ \\
\hline $\begin{array}{l}\text { ‘Old' EU * Democracy: } \\
\text { time-invariant }\end{array}$ & & & & & $\begin{array}{l}12.278^{*} \\
(6.528)\end{array}$ \\
\hline
\end{tabular}


Table A8. Conditional models 4.1-4.5: between- and within-country effects and region interactions - third part

\begin{tabular}{|c|c|c|c|c|c|}
\hline & Model 4.1 & Model 4.2 & Model 4.3 & Model 4.4 & Model 4.5 \\
\hline Political trust & GDP pc & $\begin{array}{c}\text { Corruption } \\
\text { (V-Dem) }\end{array}$ & $\begin{array}{c}\text { Corruption } \\
\text { (QOG) }\end{array}$ & Democracy & $\begin{array}{l}\text { Unemploy- } \\
\text { ment }\end{array}$ \\
\hline $\begin{array}{l}\text { ‘New' EU * Democracy: } \\
\text { time-varying }\end{array}$ & & & & & $\begin{array}{l}-0.631 \\
(1.236)\end{array}$ \\
\hline $\begin{array}{l}\text { ‘Old’ EU * Democracy: } \\
\text { time-varying }\end{array}$ & & & & & $\begin{array}{c}0.116 \\
(3.291)\end{array}$ \\
\hline
\end{tabular}

Control variables

$\begin{array}{lcllll}\text { Age } & -0.272^{* * *} & -0.272^{* * *} & -0.272^{* * *} & -0.275^{* * *} & -0.272^{* * * *} \\ & (0.016) & (0.016) & (0.016) & (0.016) & (0.016) \\ \text { Age squared } & 0.036^{* * *} & 0.036^{* * *} & 0.036^{* * *} & 0.037^{* * *} & 0.036^{* * * *} \\ & (0.002) & (0.002) & (0.002) & (0.002) & (0.002) \\ \text { Sex }(1 \text { = female) } & 0.113^{* * *} & 0.113^{* * *} & 0.113^{* * *} & 0.112^{* * *} & 0.113^{* * *} \\ & (0.010) & (0.010) & (0.010) & (0.010) & (0.010) \\ \text { Education, years } & -0.039^{* * *} & -0.039^{* * *} & -0.038^{* * *} & -0.035^{* * *} & -0.038^{* * * *} \\ & (0.003) & (0.003) & (0.003) & (0.003) & (0.003) \\ \text { 'New' EU * Education, years } & 0.028^{* * *} & 0.028^{* * *} & 0.028^{* * *} & 0.025^{* * *} & 0.028^{* * * *} \\ & (0.004) & (0.004) & (0.004) & (0.004) & (0.004) \\ \text { ‘Old' EU * Education, years } & 0.072^{* * *} & 0.072^{* * *} & 0.072^{* * *} & 0.068^{* * *} & 0.072^{* * *} \\ & (0.003) & (0.003) & (0.003) & (0.003) & (0.003) \\ \text { Income scale } & 0.113^{* * *} & 0.113^{* * *} & 0.113^{* * *} & 0.121^{* * *} & 0.113^{* * *} \\ & (0.005) & (0.005) & (0.005) & (0.005) & (0.005) \\ \text { Year } & -0.026^{* * *} & -0.002 & 0.0002 & 0.0002 & 0.0005 \\ & (0.009) & (0.005) & (0.005) & (0.005) & (0.004) \\ \text { Constant } & 4.733^{* * *} & 5.314^{* * *} & 4.626^{* * *} & 6.713^{* * *} & 6.744^{* * *} \\ & (0.544) & (0.396) & (0.509) & (1.086) & (0.646)\end{array}$

Variance components

\begin{tabular}{llllll} 
Country & 0.222 & 0.237 & 0.179 & 0.152 & 0.188 \\
Survey & 0.198 & 0.221 & 0.219 & 0.204 & 0.195 \\
Individual & 4.285 & 4.285 & 4.285 & 4.242 & 4.285 \\
\hline
\end{tabular}


Table A8. Conditional models 4.1-4.5: between- and within-country effects and region interactions-fourth part

\begin{tabular}{lcccccc}
\hline & Model 4.1 & Model 4.2 & Model 4.3 & Model 4.4 & Model 4.5 \\
\cline { 2 - 6 } Political trust & GDP pc & $\begin{array}{c}\text { Corruption } \\
\text { (V-Dem) }\end{array}$ & $\begin{array}{c}\text { Corruption } \\
\text { (QOG) }\end{array}$ & $\begin{array}{c}\text { Democracy } \\
\text { Fit statistics }\end{array}$ & $\begin{array}{c}\text { Unemploy- } \\
\text { ment }\end{array}$ \\
\hline Log Likelihood & -403504.2 & -403495.7 & -403 & 496.3 & -382934.4 & -403487.4 \\
Akaike Inf. Crit. & 807048.5 & 807031.4 & 807032.7 & 765908.8 & 807014.8 \\
Bayesian Inf. Crit. & 807250.8 & 807233.7 & 807235.1 & 766110.1 & 807217.2 \\
N individuals & 183391 & 183391 & 183391 & 174324 & 183391 \\
N surveys & 169 & 169 & 169 & 161 & 169 \\
N countries & 42 & 42 & 42 & 42 & 42 \\
\hline
\end{tabular}

Note: Standard errors in parentheses. $+\mathrm{p}<0.1,{ }^{*} \mathrm{p}<0.05,{ }^{* *} \mathrm{p}<0.01,{ }^{* * *} \mathrm{p}<0.001$.

Data source: European Values Study waves 2-5, World Values Survey waves 2, 3, 5, 6,

World Bank, Varieties of Democracy, Quality of Government. 
Figure A1. Trends in political trust and economic performance and quality of governance: Albania - Ireland
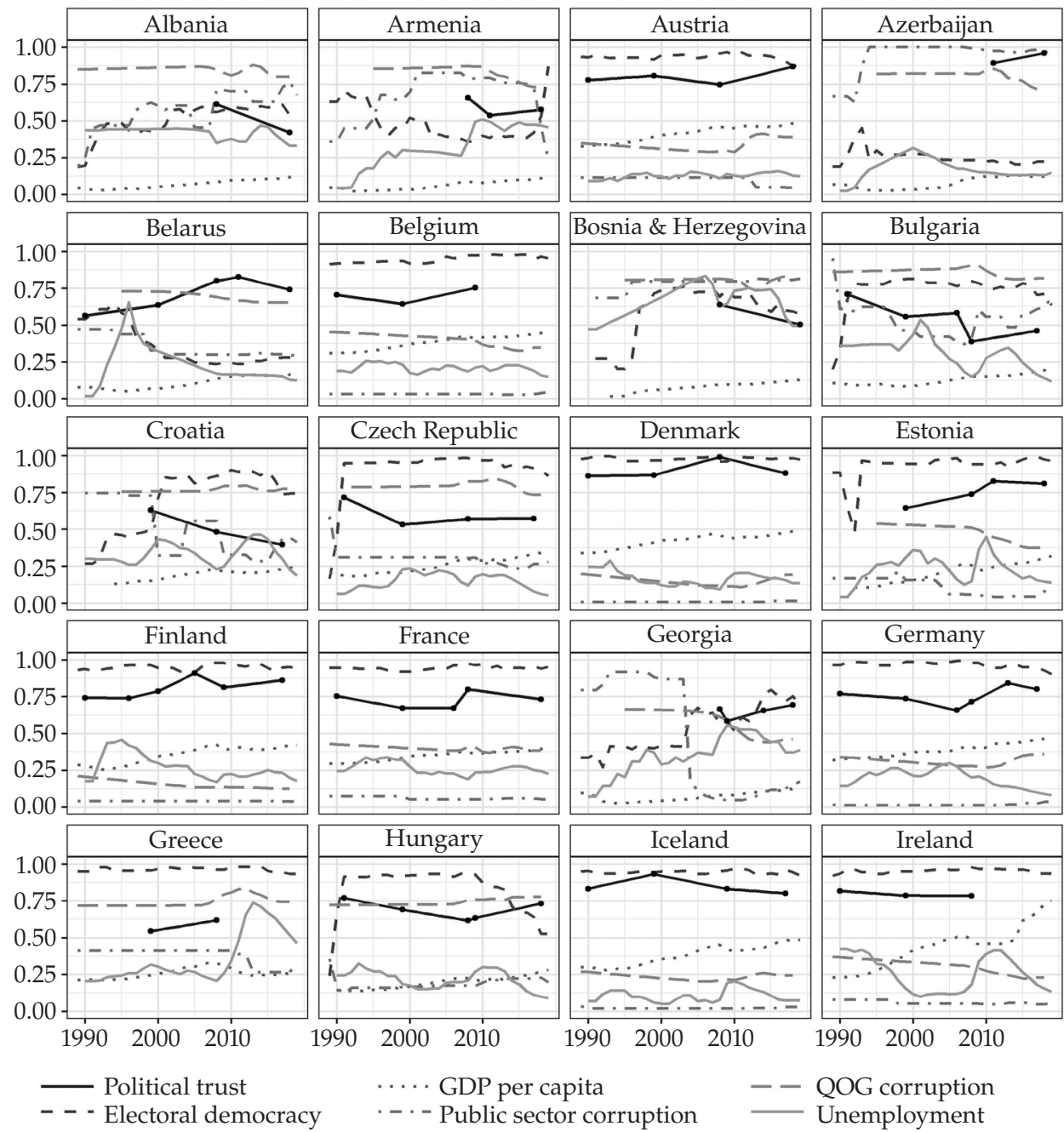

.... GDP per capita

- - - Public sector corruption

- - QOG corruption Unemployment

Note: Variables rescaled to a $0-1$ range, such that 1 corresponds to the maximum realised value across all countries in the dataset. All available values of the macro-variables between 1990 and 2019 are plotted. Points in the political trust series indicate survey measurements, while the black line connecting them is provided to facilitate reading of the graph. 
Figure A2. Trends in political trust and economic performance and quality of governance: Italy - United Kingdom
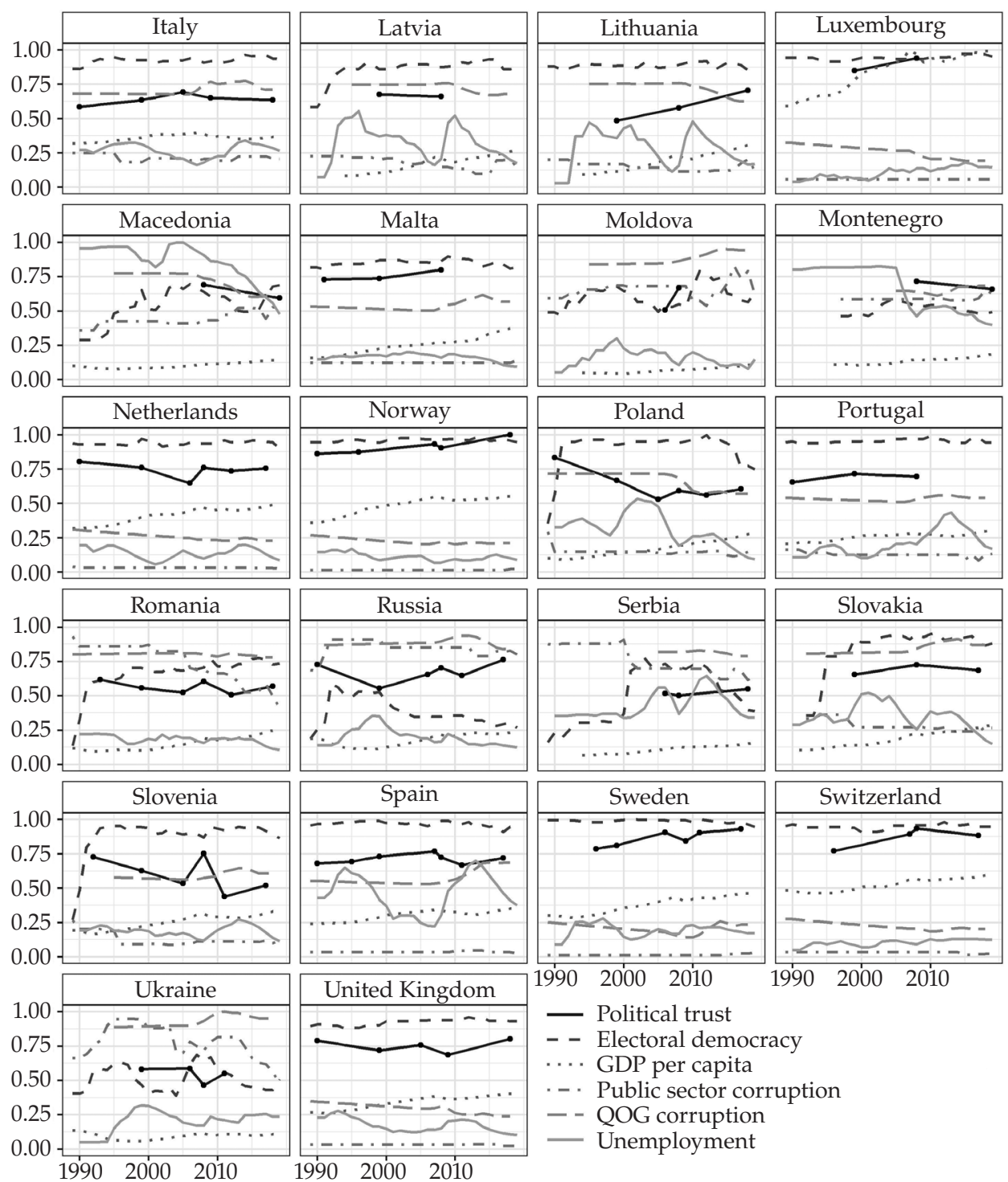

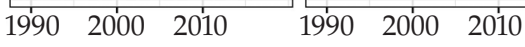

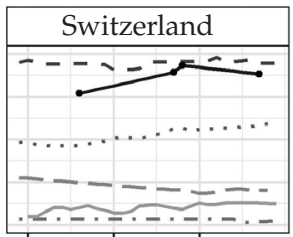

- Political trust

- - Electoral democracy

-... GDP per capita

- - Public sector corruption

- - QOG corruption

- Unemployment

Note: Variables rescaled to a $0-1$ range, such that 1 corresponds to the maximum realised value across all countries in the dataset. All available values of the macro-variables between 1990 and 2019 are plotted. Points in the political trust series indicate survey measurements, while the black line connecting them is provided to facilitate reading of the graph. 
